\title{
Bitcoin vis a vis NEO: Upaya Tiongkok menuju Penyeimbang Kekuatan Ekonomi Amerika Serikat dalam Kacamata Hegemoni dan Soft Balancing
}

\author{
Pungki Retnowati ${ }^{1}$ Ika Riswanti Putranti ${ }^{2 *}$ \\ ${ }^{1}$ Fakultas Ilmu Sosial dan Ilmu Politik, Universitas Diponegoro, Indonesia, pungkiretnowati2105@ gmail.com \\ ${ }^{2}$ Fakultas Ilmu Sosial dan Ilmu Politik, Universitas Diponegoro, Indonesia, ikarisp@ gmail.com
}

\begin{abstract}
ABSTRAK
Bitcoin merupakan salah satu cryptocurrency yang terkenal sejak 2013 diseluruh dunia dimana konsepnya adalah P2P atau terdesentralisasi antar server user dalam sebuah jaringan. Nilai tukar Bitcoin terus meningkat seiring permintaan dari seluruh dunia, termasuk Tiongkok sebagai salah satu negara dengan transaksi ekonomi terbesar didunia. Lebih dari 50\% transaksi Bitcoin dunia dilakukan melalui cryptomarket asal Tiongkok. Selain itu, Tiongkok juga menjadi negara dengan industri mining pool Bitcoin terbesar didunia. Hal tersebut menjadikan Tiongkok sebagai negara dengan nilai perputaran Bitcoin terbesar didunia. Besarnya arus perputaran Bitcoin di Tiongkok tampaknya menjadi ancaman tersendiri bagi Pemerintah Tiongkok sehingga pada September 2017, Pemerintah Tiongkok mengeluarkan kebijakan pelarangan transaksi ICO dan menutup BTCC yang merupakan salah satu cryptomarket Bitcoin terbesar didunia. ICO dapat diartikan sebagai konsep investasi cryptocurrency dengan tujuan crowd funding. Sebulan setelah mengeluarkan larangan transaksi ICO, Pemerintah Tiongkok justru mengumumkan rencana Pemerintah Tiongkok untuk mengembangkan dunia blockchain (cryptocurrency) sendiri. Penelitian ini menjelaskan alasan kebijakan pemerintah Tiongkok terkait pelarangan ICO dan penutupan BTCC namun justru mengembangkan cryptocurrency sendiri menggunakan konsep hegemoni dan soft balancing dalam pendekatan realisme. Hasil penelitian menunjukkan bahwa kebijakan pemerintah Tiongkok yang melarang ICO dan penutupan BTCC merupakan langkah yang diambil dalam upaya Tiongkok untuk menyeimbangi Amerika Serikat sebagai negara berpengaruh di bidang ekonomi didunia.
\end{abstract}

Kata Kunci : Bitcoin, Tiongkok, ICO, Hegemoni, Soft Balancing

\begin{abstract}
Bitcoin is one of the most famous cryptocurrency since 2013 around the world where the concept is $P 2 P$ or decentralized between user servers in a network. Bitcoin exchange rates continue to increase as demand from all over the world, including China as one of the countries with the largest economic transactions in the world. More than 50\% of the world's Bitcoin transactions are carried out through cryptomarket from China. In addition, China is also the country with the world's largest Bitcoin mining pool industry. This makes China to be the country with the largest Bitcoin turnover in the world. The large circulation of Bitcoin in China seems to be a threat to the Chinese Government so that in September 2017, the Chinese Government issued a policy prohibiting ICO transactions and closing the BTCC which is one of the largest Bitcoin cryptomarket in the world. ICO can be interpreted as a cryptocurrency investment concept with the goal of crowd funding. A month after issuing a ban on ICO transactions, the Chinese Government announced the Chinese Government's plan to develop its own blockchain (cryptocurrency) world. This study explains the reasons for the Chinese government's policies related to the ICO ban and BTCC closure but instead developed its own cryptocurrency using the concept of hegemony and soft balancing in the realism approach. The results show that the Chinese government's policy that prohibits ICO and BTCC closure is a step taken in China's efforts to balance the United States as an influential country in the world economy.
\end{abstract}

Keywords: Bitcoin, China, ICO, Hegemony, Soft Balancing 


\section{Pendahuluan}

Cryptocurrency merupakan mata uang digital yang diciptakan dengan teknologi kriptografis terdesentralisasi blockchain. Berdasarkan data dari Coin Market Cap hingga Febuari 2019, terdapat 2093 jenis cryptocurrency yang beredar di dunia, dimana salah satunya adalah Bitcoin ${ }^{1}$. Bitcoin merupakan mata uang digital yang dikembangkan oleh seorang ahli bernama Satoshi Nakamoto (nama samara) menggunakan teknologi kriptografi, prinsip P2P, dan skema terdesentralisasi sehingga pada transaksi Bitcoin tidak diperlukan perantara pihak ketiga seperti pada transaksi konvensional dimana bank atau penyedia jasa keuangan lainnya merupakan provider untuk setiap transaksi.

Bitcoin digunakan hampir diseluruh dunia. Pada awal kemunculannya, pasar perputaran Bitcoin terbesar didunia dikuasai oleh masyarakat pasar Eropa dan Amerika Serikat. Namun, dimulai pada sekitar Oktober 2013, masyarakat Tiongkok mulai menggunakan Bitcoin sebagai salah satu alat transaksi, dimana transaksi setiap harinya di Tiongkok mencapai 50\% dari total transaksi Bitcoin di dunia yaitu 22.000 BTC atau sekitar $\$ 110$ juta dollar. Sedangkan ketika masyarakat Tiongkok mulai menggunakan Bitcoin, pangsa total perdagangan dalam dolar AS turun menjadi kurang $10 \%$. Dengan demikian, pasar Bitcoin Tiongkok menjadi sangat menentukan harga Bitcoin di seluruh dunia. Hal tersebut tentunya di manfaatkan oleh pemerintah Tiongkok sebagai kesempatan untuk menarik devisa dari berbagai negara untuk masuk ke Tiongkok melalui para trader Bitcoin di Tiongkok.

Sebagai negara yang menguasai pasar Bitcoin, Tiongkok mempunyai pengaruh besar terhadap perputaran harga Bitcoin dunia.

\footnotetext{
1 All Cryptocurrencies | Coinmarketcap. (2019, January 10). Retrieved from https://coinmarketcap.com/all/views/all/.
}

Namun, pada September 2017, pemerintah Tiongkok mengejutkan dunia mata uang digital ketika beralih untuk melarang langkah transaksi ICO, sarana bagi start-up untuk menghimpun dana dengan melepas cryptocurrency baru, serta menutup bursa pertukaran cryptocurrency di dalam negeri. Lebih mengejutkan lagi, pemerintah Tiongkok melalui PBOC menyatakan bahwa Tiongkok akan mengembangkan cryptocurrency sendiri. ICO sendiri merupakan konsep investasi baru yang mucul bersamaan dengan munculnya cryptocurrency dengan tujuan "crown funding" atau pengumpulan dana dari publik pada industri cryptocurrency dan blockchain. Munculnya konsep ICO membuat masyarakat meninggalkan konsep pengumpulan dana tradisional melalui perbankan atau pemerintah, sehingga memungkinkan dana yang terkumpul jumlahnya sangat besar dan tidak terbatas.

Amerika merupakan salah satu negara dengan pasar crypto terbesar juga. Sebagaimana telah dijelaskan sebelumnya bahwa adanya teknologi kriptografi yang memungkinkan untuk crowd funding, memberikan manfaat tersendiri khususnya bagi pelaku bisnis di Amerika. Bahkan penggunaan cryptocurrency merupakan hal yang familiar dan bukan hal yang baru bagi masyarakat Amerika. Salah satu cryptocurrency yang mempunyai pengguna terbesar di Amerika adalah Bitcoin. Berdasarkan data dari (You Gov Omnibus , 2018 ) sekitar 157 juta penduduk Amerika Serikat atau sekitar 48\% dari jumlah penduduk Amerika Serikat merupakan masyarakat yang familiar dan tertarik untuk menggunakan cryptocurrency sebagai mata uang utama ${ }^{2}$. Bahkan, penggunaan cryptocurrency khususnya Bitcoin telah digunakan sebagai media pembayaran utama dalam berbagai merchant baik secara online atau secara konvensional. Selain itu, Amerika juga merupakan negara peringkat

\footnotetext{
2 You Gov Omnibus. Cryptocurrency . San Fransisco: You Gov Omnibus . 2018
} 
pertama dengan jumlah ATM Bitcoin terbesar didunia. Adanya ATM tersebut dapat dijadikan indikasi bahwa Bitcoin memiliki hubungan secara langsung dengan ekonomi dunia nyata. Selain itu proses liquidasi Bitcoin tidak bergantung kepada market konvensional seperti bank yang mempunyai batasan hari dan jam kerja.

Cryptocurrency khususnya Bitcoin dijalankan atas dasar perputaran yang berkaitan dengan jumlah permintaan dari user. Semakin banyak user yang menggunakan, maka nilai capital marketnya juga akan naik. Semakin besar nilai capital market maka pengguna juga akan semakin percaya. Dengan adanya pergeseran pusat perputaran ke Tiongkok, maka Tiongkok mempunyai kemampuan untuk menentukan nilai tukar Bitcoin.

\section{Tinjauan Pustaka}

Sejauh ini belum ada penelitian yang membahas secara spesifik mengenai topik ini. Namun ada satu jurnal yang diterbitkan oleh Houston Journal of International Law. Dalam jurnal tersebut dijelaskan mengenai sejarah singkat mengenai cryptocurrency, pandangan legal dan illegal dari transaksi yang menggunakan Bitcoin, serta respon secara general dari beberapa negara seperti China, Jerman, dan Kanada.

Oleh sebab itu, penelitian ini bertujuan untuk menjelaskan secara lebih spesifik mengapa pemerintah Tiongkok mengeluarkan kebijakan pelarangan transaksi ICO dan melakukan penutupan pasar Bitcoin (BTCC) ketika Tiongkok masih memegang kendali lebih dari $50 \%$ transaksi Bitcoin dunia pada tahun 2017. Penelitian ini akan menggunakan konsep soft balancing dan hegemony untuk menjelaskan mengapa hal tersebut dapat terjadi.

\section{Konsep Soft Balancing}

Realisme muncul sebagai reaksi keras terhadap kegagalan paradigma Liberalisme dalam mencegah agresivitas negara tertentu, dengan adanya otoritas yang berada diatas negara yang akan dapat menciptakan perdamaian. Perang Dunia II merupakan bukti kegagalan paradigma Liberalisme. Inti dari serangan kaum Realis adalah bahwa analisis kaum Liberalis terhadap fenomena politik internasional yang mendasarkan pada asumsi bahwa negara seperti layaknya individu memiliki kecenderungan baik dan saling bergantung satu sama lain merupakan sebuah kekeliruan. $^{3}$

Adapun argumen argumen utama dari Realis menurut E.H Carr adalah sebagai berikut: (1) Kritik terhadap gagasan keamanan kolektif (colective security): Konsep Keamanan Kolektif yang diterapkan oleh Liga Bangsa Bangsa dengan mengacu pada pandangan Liberal bahwa manusia pada dasarnya berkecenderungan baik untuk saling bekerja sama terbukti gagal. Kegagalan ini merupakan akibat asumsi Liberal tentang perilaku negara yang keliru, dimana fakta menunjukkan bahwa negara berkecenderungan egoistik dan agresif sehingga tidak mungkin membentuk suatu Keamanan Kolektif; (2) Kritik terhadap konsep Harmoni Kepentingan (Harmony of Interest): Ide harmoni kepentingan yang digagas oleh kaum Liberal dan diyakini mampu menggerakkan kerja sama internasional hanya ada dalam angan-angan saja karena pada kenyataannya dalam kondisi politik internasional yang anarkis setiap negara akan memperjuangkan kepentingan masing masing secara egosentrik; (3) Kekuasaan sebagai unsur utama politik internasional : Hakikat dari politik internasional adalah kekuasaan (power) yang ditopang oleh tiga unsur penting : (a) kekuatan militer (military power), (b) kekuatan ekonomi (economic power), dan (c) kekuatan untuk mempengaruhi (power over opinion) yang mempunyai peran penting dalam menjaga kelangsungan hidup suatu negara; (4) Tidak ada moralitas dalam politik internasional : Moralitas dalam politik internasional merupakan nonsense karena

3 Hadiwinata, Bob Sugeng. Realisme dan Neorealisme. In Studi dan Teori Hubungan Internasional (pp 102). Jakarta: Yayasan Pustaka Obor Indonesia. 2017. 
pandangan tersebut didasarkan pada personifikasi negara sebagai perwujudan dari individu yang kooperatif dan berperilaku baik. ${ }^{4}$

Pada masa Perang Dingin, kepentingan nasional negara berubah dari fokus perlindungan integritas teritorial menjadi pemeliharaan stabilitas dan pedamaian dalam situasi perimbangan kekuatan atau yang lebih dikenal sebagai Balance of Power. Teori balance of power tradisional mengatakan bahwa jika suatu negara merasa terancam oleh suatu hegemon, maka negara akan akan bergabung dengan negara lain yang lebih lemah supaya kelangsungan hidupnya dapat dipertahankan. ${ }^{5}$ Namun, ada hal yang perlu diingat, bahwa kekuatan disini biasanya diidentikkan dengan kekuatan militer. ${ }^{6}$

Paska Perang Dingin, sistem internasional terbentuk menjadi unipolar dimana Amerika Serikat merupakan satusatunya great power di dunia. Dengan kekuatan relatif Amerika yang jauh lebih besar dibandingkan dengan negara lain, banyak yang menganggap bahwa tidak akan banyak negara yang berusaha mengimbangi Amerika, terlebih ketika sikap Amerika menjadi begitu unilateral paska serangan 9/11. ${ }^{7}$ Namun beberapa negara telah mencoba cara lain untuk mengimbangi hegemoni Amerika meskipun dibidang selain militer. Sikap negara dalam mencoba mengimbangi hegemoni tersebut dapat dijelaskan dengan konsep soft balancing. Pape. ${ }^{8}$ mendefinisikan soft balancing sebagai tindakan nonmiliter yang digunakan untuk "delay, frustrate, and undermine" kebijakan militer Amerika yang agresif dan unilateral.

\footnotetext{
${ }^{4}$ Ibid, 106.

5 Bull, Hedley, Herbert Butterfield, and Kenneth Walt. Theory of International Politics. California: Addison. 1979.

${ }^{6}$ Dunne, Tim, and Brian C. Schmidt.. Realism. In John Baylis and Steve Smith, The Globalization of World Politics (pp 161-183). New York: Oxford. 2001.

${ }^{7}$ Hadiwinata, Bob Sugeng. Loc. Cit.

${ }^{8}$ Pape, Robert A. Soft Balancing against the United States. International Security, 30, 7-45. 2005
}

Soft balancing dapat dilakukan dengan 4 cara: (a) penolakan akses terhadap wilayah (oleh negara lemah terhadap hegemon); (b) diplomasi; (c) memperkuat ekonomi; dan (d) memberi sinyal terhadap negara pemimpin unipolar akan adanya tindakan balancing misalnya dengan membentuk koalisi atau institusi internasional. ${ }^{9}$

Penggunaan konsep soft balancing juga telah digunakan oleh beberapa penulis sebagai paradigma untuk menjelaskan berbagai isu isu internasional. Max Paul Friedman dan Tom Long dalam jurnalnya yang berjudul "Soft Balancing in the Americas - Latin American Opposition to U.S. Intervention, 1898-1936" menjelaskan bahwa diplomasi antara negara negara Amerika Latin dengan Amerika merupakan bagian dari upaya soft balancing dari negara negara non Amerika kepada Amerika. Balancing dapat diartikan sebagai upaya otonomi negara, kemerdekaan, dan kemampuan untuk mempengaruhi hasil internasional vis-à-vis negara kuat atas sekelompok negara berkaitan dengan ancaman serangan langsung dari mereka. ${ }^{10}$ Dalam hal tersebut, dapat dijelaskan melalui definisi soft balancing Pape yang juga digunakan dalam penelitian tersebut. Negara negara Amerika Latin menggunakan dasar norma non intervention dalam melakukan diplomasi terhadap Amerika yang melakukan intervensi terhadap Irak pada saat itu. Hal tersebut merupakan upaya bagian dari soft balancing yaitu diplomasi dan koalisi negara negara. Selain itu terdapat pula penelitian lain yang juga menggunakan soft balancing sebagai paradigma untuk menjelaskan suatu isu. Dalam jurnalnya yang berjudul "Soft Balancing In Turkish Foreign Policy: The Case Of The 2003 Iraq War", Murat Yeşiltaş menjelaskan bahwa kebijakan luar negeri Turki yang diambil pada saat itu, berkaitan dengan intervensi Amerika

\footnotetext{
${ }^{9}$ Ibid.

10 Friedman, M. P. and Long, T. Soft balancing in the Americas: Latin American opposition to U.S. intervention, 1898 - 1936. International Security, 120-156. 2015
} 
terhadap Irak merupakan bagian dari upaya soft balancing. Yeşiltaş menekankan bahwa soft balancing bukanlah upaya yang dilakukan dengan menggabungkan kekuatan militer, melainkan menggabungkan aset diplomatiknya untuk melindungi kepentingannya. ${ }^{11}$ Beberapa tindakan Turki seperti tidak menginzinkan tentara Amerika untuk mendarat di Turki dan melakukan pertemuan dengan negara negara tetangga Timur Tengah untuk membahas mengenai Irak merupakan bagian dari upaya soft balancing yaitu penolakan akses terhadap wilayah dan melakukan koalisi negara negara sebagai signal serta pembatasan terhadap negara unipolar.

Dari penjelasan Pape, cara (c) relevan untuk menganalisis kebijakan pemerintah Tiongkok dalam melakukan pelarangan transaksi ICO ketika Tiongkok menguasai 70\% transaksi Bitcoin, penutupan pasar BTCC, dan rencana pengembangan cryptocurrency sendiri. Tiongkok merupakan negara dengan jumlah penduduk yang menempati urutan pertama dunia yang telah berhasil bangkit mengubah sistem ekonomi dari tertutup menjadi ekonomi pasar. Sehingga menjadikan Tiongkok merupakan salah satu negara dengan tingkat investasi dan transaksi tinggi. Pada saat pemerintah Tiongkok mengeluarkan kebijakan pelarangan transaksi ICO yang justru membatasi masyarakat untuk bertransaksi dengan bebas ditengah tengah keberhasilan Tiongkok untuk menguasai sebagian besar pasar Bitcoin dunia, pemerintah justru mengeluarkan pernyataan melalui PBOC untuk mengembangkan cryptocurrency sendiri. Mengingat Tiongkok masyarakatnya memiliki network investasi dan transaksi bisnis yang luas didunia, maka pengembangan cryptocurrency sendiri oleh pemerintah Tiongkok merupakan langkah pemerintah Tiongkok untuk memperkuat ekonomi Tiongkok guna meningkatkan perannya

11 Yeşiltaş, Murat. Soft Balancing In Turkish Foreign Policy: The Case Of The 2003 Iraq War. Perceptions, 1-27. 2009 didalam politik Internasional. Selain untuk memperkuat ekonomi, pengembangan cryptocurency sendiri oleh pemerintah Tiongkok merupakan langkah untuk menyeimbangi Amerika sebagai negara unipolar mengingat jumlah penduduk Tiongkok dan tingkat transaksi Tiongkok baik melalui investasi maupun industri. Hal ini sesuai dengan salah satu poin poin argumen utama Realis yang dikatakan oleh E.H Carr, bahwa salah satu unsur utama politik internasional adalah kekuatan ekonomi

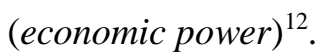

\section{Konsep Hegemony}

Konsep hegemony merupakan turunan dari Realis, yang dapat dipahami sebagai suatu keadaan dimana ada suatu aktor atau negara yang menguasai atau mempunyai kelebihan kemampuan (capability) dibandingkan dengan aktor-aktor lainnya sehingga mampu mendominasi atau hegemon juga dapat diartikan sebagai kekuatan yang mendominasi. Menurut Ikenberry dan Kupchan hegemony merupakan dominasi satu negara atas negara lain dalam kemampuan militer, ekonomi, sosial budaya atau kemampuan komprehensif lainnya. ${ }^{13}$ Antara negara satu dengan yang lain yang mempunyai kemampuan hegemon memiliki fokus dominasi yang berbeda beda bergantung kepada kemampuan dominasi apa yang dimilikinya sehingga mampu menundukkan dan meningkatkan perannya dalam sistem internasional. Menurut Dirzauskaite bahwa hegemony bergantung pada dua faktor yaitu: kemampuan aktor untuk memiliki kekuatan dan kemauan yang cukup untuk melakukannya. ${ }^{14}$

Penggunaan konsep hegemony juga telah digunakan oleh beberapa penulis sebagai paradigma untuk menjelaskan berbagai isu isu

\footnotetext{
${ }^{12}$ Hadiwinata, Bob Sugeng. Loc.Cit.

${ }^{13}$ Dirzauskaite, Goda, and Nicolae Cristinel Ilinca. Understanding "Hegemony" in International Relations Theories. Development and International Relations Aalborg University, 18. 2017
}

${ }^{14}$ Ibid. 
internasional. Dalam jurnalnya yang berjudul "Chinese views of US Hegemony", Samantha menjelaskan bahwa Amerika memiliki kekuatan dan pengaruh yang sangat besar baik secara militer, ekonomi, sosial atau budaya yang dapat mendorong Amerika untuk bertindak arogan dan agresif, dimana tindakan arogan dan agresif tersebut akan mendorong sebuah negara untuk berperilaku sebagaimana negara hegemon. ${ }^{15}$ Selain itu terdapat pula penelitian lain yang juga menggunakan hegemony sebagai paradigma untuk menjelaskan suatu isu. Dalam jurnal yang berjudul "The US dollar and its challenges: American hegemony in the $21^{\text {st }}$ century", Thomas Costigan menjelaskan bahwa Amerika merupakan negara hegemon sejak berakhirnya Perang Dunia Kedua. Hal ini disebabkan oleh adanya eksistensi Dollar Amerika sebagai mata uang cadangan global dalam perdagangan dan investasi internasional. ${ }^{16}$ Jurnal tersebut menjelaskan bahwa Amerika melalui Dollar-nya memiliki hegemony dalam bidang ekonomi global.

Dari penjelasan Dirzauskaite dan Ilinca diatas, konsep hegemony relevan untuk melihat kebijakan pemerintah Tiongkok yang telah merangkak untuk dapat berdiri menciptakan suatu hegemon baru menggantikan hegemon yang sebelumnya telah dipegang oleh Amerika yang kini telah menurun. Dengan economic network yang dijalankan masyarakat Tiongkok, gagasan cryptocurrency milik Tiongkok sendiri nantinya akan menjadi jalan bagi Tiongkok untuk menjadi negara yang mempunyai hegemon yang berpengaruh baik di kawasan regional maupun internasional.

15 Blum, Samantha. Chinese Views of US Hegemony. Journal of Contemporary China, 239 264. 2003

16 Costigan, Thomas. The US dollar and its challenges: American hegemony in the 21st century. Journal Labor and Society. 2018

\section{Faktor Pelarangan ICO dan Penutupan BTCC oleh Pemerintah Tiongkok}

Cryptocurrency merupakan suatu terobosan besar dalam dunia fin-tech yang dijalankan dengan sistem peer to peer, dimana setiap komputer akan terhubung secara langsung dengan komputer lainnya dalam suatu network tertentu dan dengan suatu algoritma tertentu diseluruh dunia. Saat ini, hampir disetiap negara memiliki cryptomarket yang melayani proses trading dan liquidasi dari aset digital tersebut, termasuk Amerika.

Amerika merupakan salah satu negara yang mempunyai pasar besar terhadap cryptocurrency. Penggunaan cryptocurrency merupakan hal yang familiar dan bukan hal yang baru bagi masyarakat Amerika. Salah satu cryptocurrency yang memunyai pengguna terbesar di Amerika adalah Bitcoin. Berdasarkan data dari (You Gov Omnibus , 2018 ) sekitar 157 juta penduduk Amerika Serikat atau sekitar $48 \%$ dari jumlah penduduk Amerika Serikat merupakan masyarakat yang familiar dan tertarik untuk menggunakan cryptocurrency sebagai mata uang utama. Bahkan, penggunaan cryptocurrency khususnya Bitcoin telah digunakan sebagai media pembayaran utama dalam berbagai merchant baik secara online atau secara konvensional. Setidaknya lebih dari 50 perusahaan besar dan merchant berskala internasional asal Amerika telah menggunakan Bitcoin sebagai media pembayaran. Amerika merupakan salah satu negara dengan pasar cryptocurrency terbesar didunia. Hal ini didukung dengan adanya mesin ATM yang mendukung terhadap adanya transaksi cryptocurrency. Berikut ini adalah data persebaran ATM crypto secara global berdasarkan (Huillet, 2019) ${ }^{17}$ :

17 Huillet, M. (2019, Januari 11). Almost 5 New Cryptocurrency ATMs Installed Worldwide Each Day, Data Shows. Retrieved from: https://cointelegraph.com/news/almost-5-newcryptocurrency-atms-installedworldwide-each-daydata-shows 


\section{Gambar 1. Data Persebaran ATM Bitcoin di Seluruh Dunia per Januari 2019}

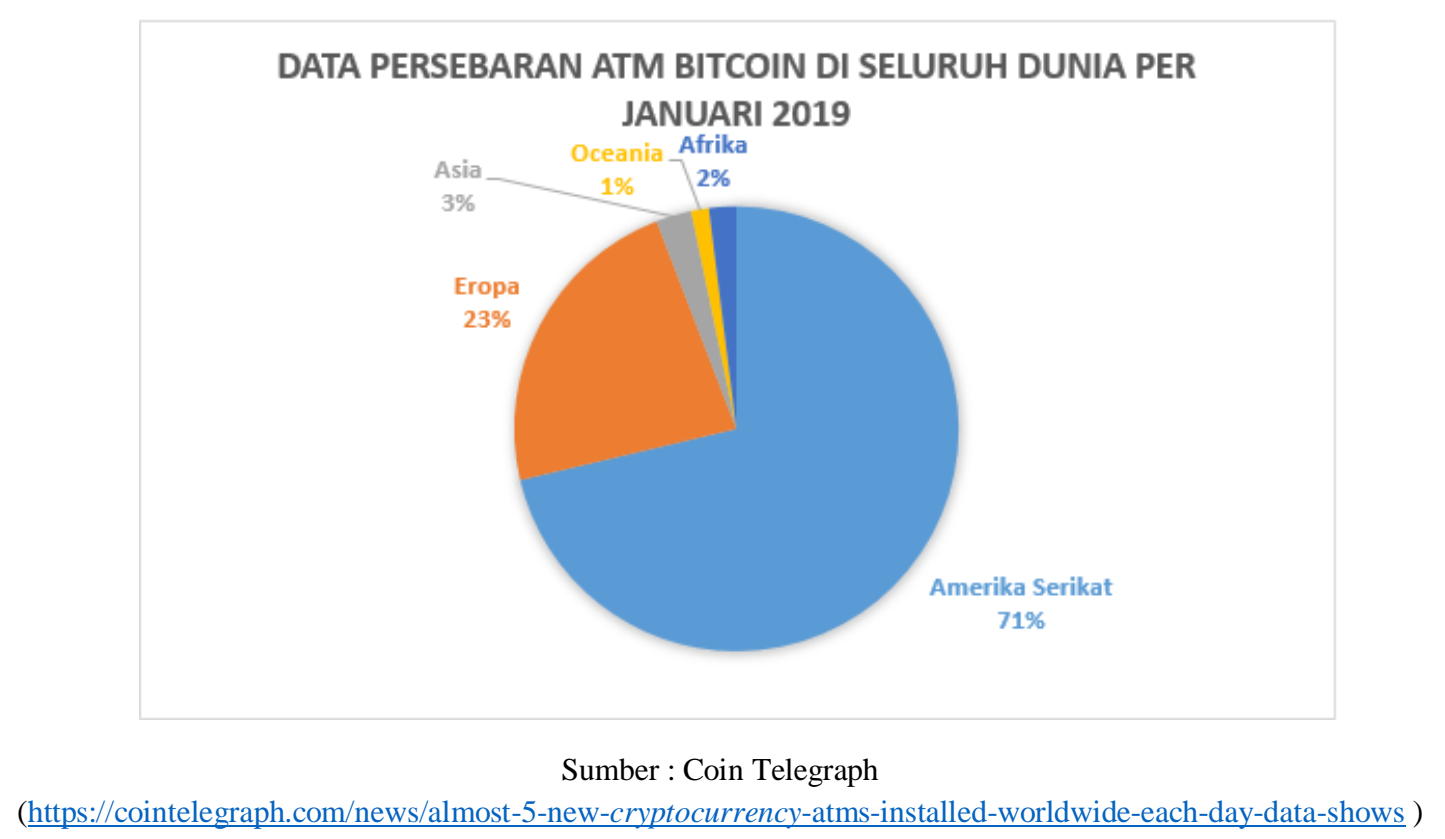

Dari gambar grafik tersebut dapat dilihat bahwa penggunaan cryptocurrency merupakan hal yang familiar dan bahkan mempunyai fasilitas yang memadai dalam membantu terhadap transaksi cryptocurrency. Hal tersebut dikarenakan adanya fitur-fitur dari cryptocurrency seperti P2P, dan terdesentralisasi dimana dengan adanya fitur tersebut, tidak akan ada biaya tambahan yang dikenakan kepada setiap user yang melakukan transaksi. Selain itu, penggunaan cryptocurrency dalam hal ini Bitcoin sebagai media transaksi akan memberikan keuntungan tersendiri bagi usernya, karena Bitcoin hasil referensi yang didapat dari transaksi sebelumnya dapat digunakan sebagai media investasi. Adanya fasilitas ATM yang menyediakan Bitcoin memberikan keuntungan lebih bagi user karena dengan adanya fasilitas ATM tersebut, membuktikan bahwa cryptocurrency memiliki hubungan secara langsung dengan ekonomi dunia nyata selain itu proses liquidasi Bitcoin tidak bergantung kepada market konvensional yang mempunyai batasan hari dan jam kerja.
Selain itu, melihat kedalam faktor domestik Amerika perlu diperhatikan bahwa Dollar Amerika sepanjang 104 terakhir telah kehilangan hampir $96 \%$ nilainya. Terlepas dari perjalanan sejarah Dollar Amerika, kebijakan presiden Donald Trump mengenai perdagangan proteksionisnya akan memberikan potensi inflasi lebih lanjut di Amerika. Dengan adanya kebijakan tersebut, Trump memberikan pajak impor barang lebih tinggi sehingga barang impor akan lebih sedikit masuk ke Amerika. Selain itu, adanya hal tersebut akan membuat investor dari luar negeri akan berbondong bondong masuk ke Amerika dan membuat industri sendiri di Amerika. Hal tersebut tentunya akan memicu perang dagang yang besar melihat negara negara pengekspor besar seperti Tiongkok tidak dapat masuk ke pasar Amerika. Dilihat dari sudut pandang dalam negeri, mungkin hal tersebut dapat memberikan hal positif mengingat neraca perdagangan Amerika yang selalu defisit setiap bulannya. Kebijakan untuk memperkecil impor dan memperbesar ekspor 
tersebut memberikan dampak tersendiri bagi dunia IPO dimana index saham langsung mengalami penurunan tajam. Ketika dunia IPO terguncang, tidak mengherankan bahwa masyarakat Amerika mulai tidak mempercayai pemerintah. Sebagaimana telah dijelaskan sebelumnya bahwa cryptocurrency khususnya Bitcoin merupakan sebuah nilai yang mempunyai nilai apabila banyak masyarakat yang percaya dan menggunakannya, karena pada hakikatnya nilai tukar Bitcoin ditentukan oleh mekanisme pasar yaitu tingkat penawaran dan tingkat permintaan. Sehingga masyarakat Amerika mulai beralih kedalam dunia ICO dalam hal ini Bitcoin untuk menjaga daya beli Dollar mereka.

Negara merupakan kumpulan dari individu individu yang mempunyai pandangan yang sama dan menempati suatu geografis tertentu. Seorang individu mempunyai hakikat untuk berlaku agresif dan egosentris untuk memperjuangkan kepentingannya, begitu juga negara yang mempunyai hakikat seperti manusia. ${ }^{18}$ Tiongkok merupakan salah satu negara yang mempunyai peran besar terhadap perkembangan dunia cryptocurrency, khususnya Bitcoin. Pada tahun 2013, Tiongkok telah berhasil membuat nilai tukar Bitcoin naik tajam dari US\$ 300 menjadi US \$ 1200 kurang dari sebulan. Adanya kenaikan nilai tukar tersebut, menyebabkan banyak investor Tiongkok mulai ikut berinvestasi menggunakan Bitcoin sehingga dalam kurun 2013-2017 Tiongkok menjadi negara dengan pusat pertukaran Bitcoin terbesar dunia. Hal tersebut didukung dengan banyaknya para pengusaha di Tiongkok yang beralih profesi menjadi miner. Pada September 2017, pemerintah Tiongkok melalui PBOC mengeluarkan larangan terhadap transaksi berbasis ICO dan menutup pasar pertukaran Bitcoin-RMB BTCC. Perintah larangan tersebut diperketat dengan adanya pelarangan adanya seminar atau acara yang berkaitan dengan transaksi ICO. Pemerintah juga melakukan tindakan tegas terhadap restoran atau merchant yang melakukan transaksi ICO, bahkan pemerintah juga melakukan pemblokiran akun publik pada aplikasi WeChat yang menggunakan transaksi ICO oleh pemerintah Tiongkok. Sebagai teknologi finansial baru, penggunaan transaksi basis ICO khususnya Bitcoin tentu saja memiliki ancaman atau resiko terhadap perekonomian suatu negara.

Faktor pertama yang melatar belakangi perintah larangan transaksi berbasis ICO dan penutupan pasar BTCC oleh pemerintah Tiongkok adalah resiko pecahnya bubble investation. Berdasarkan data dari Oyedele, Tiongkok merupakan negara yang mendominasi pasar global Bitcoin dalam rentang waktu 2013- 2017. ${ }^{19}$ Hal ini didukung dengan adanya grafik yang direkam secara otomatis oleh Blockchain yang menunjukkan tingginya pertukaran Bitcoin ke RMB dari waktu kewaktu. Para investor Tiongkok kebanyakan menggunakan Bitcoin sebagai ladang investasi atau usaha tambang (mining) dan bukan digunakan sebagai transaksi harian (high frequency). Hal tersebut menjadikan Tiongkok sebagai pusat investasi cryptocurrency global. Seperti yang telah diketahui bahwa skema Bitcoin P2P yang terdesentralisasi membuat tidak adanya pihak ketiga yang dapat mengontrol setiap transaksi Bitcoin yang ada, termasuk negara. Sedangkan nilai tukar Bitcoin hanya ditentukan oleh sistem permintaan dan penawaran pasar sehingga dapat berubah setiap detiknya. Oleh sebab itu, jika suatu saat nilai tukar Bitcoin jatuh sedangkan banyak investor Tiongkok yang masih berinvestasi pada Bitcoin, tentunya hal tersebut akan mempengaruhi perekonomian Tiongkok. 


\section{Gambar 2. Data Persebaran Volume Trading Bitcoin Januari 2012 hingga Januari 2017}

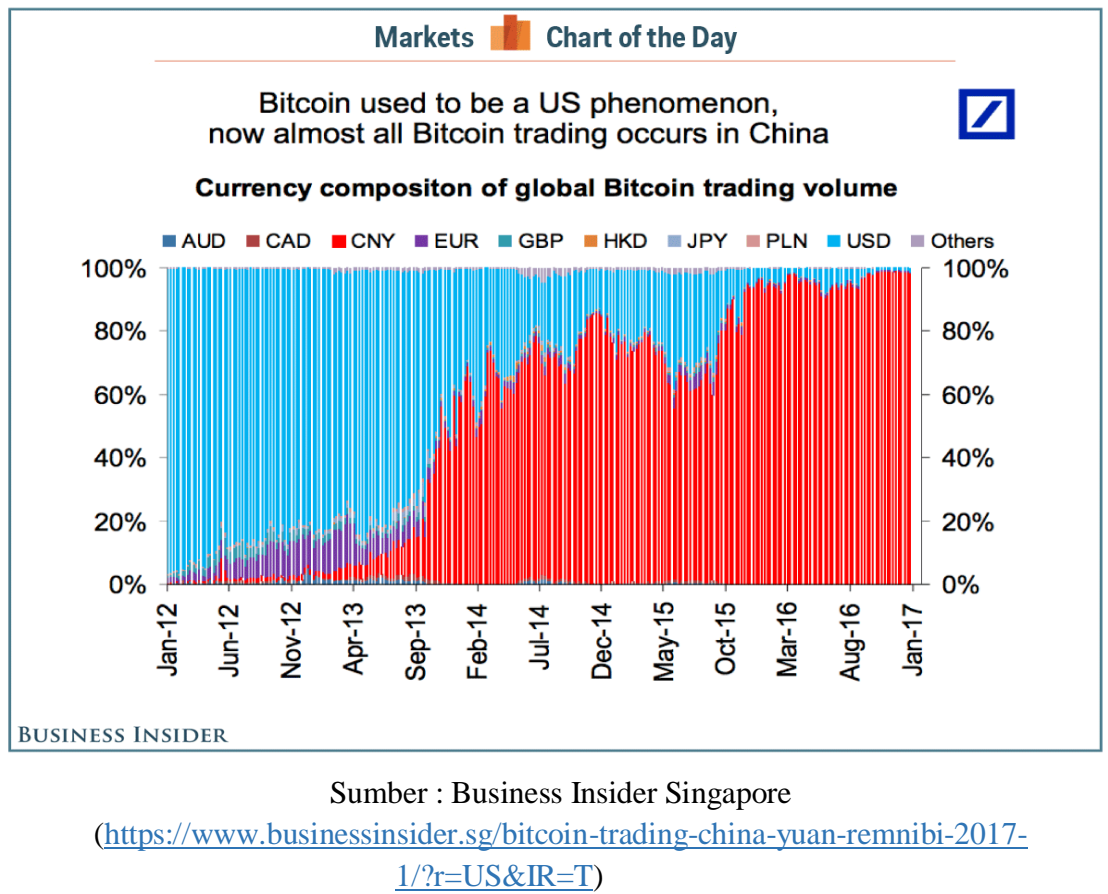

Faktor selanjutnya yang melatar belakangi perintah larangan transaksi berbasis ICO dan penutupan pasar BTCC oleh pemerintah Tiongkok adalah penggunaan Bitcoin sebagai pendanaan tindakan tindakan ilegal. Sebagaimana yang telah dijelaskan sebelumnya bahwa Bitcoin mempunyai sistem yang memungkinkan seorang pengguna dapat melakukan transaksi tanpa diketahui identitasnya, meskipun setiap transaksinya akan secara otomatis tercatat dalam blockchain. Skema anonymous dan P2P inilah yang mendorong para pelaku kejahatan memilih untuk menggunakan Bitcoin sebagai media dalam bertransaksi. Meskipun demikian, tidak menutup kemungkinan untuk dilakukan penyelidikan terhadap transaksi yang mengindikasikan transaksi ilegal. Bentuk bentuk kejahatan atau transaksi ilegal yang dapat dilakukan dengan Bitcoin beragam. Menurut data dari Cipher Trace beberapa tindakan ilegal yang berkaitan dengan cryptocurrency dengan presentase tertinngi diantaranya adalah serangan malware dengan tebusan Bitcoin, pencucian uang, pendanaan aksi terorisme, serta situs pasar gelap online. ${ }^{20}$

Berdasarkan data dari CipherTrace, dari seluruh transaksi Bitcoin yang terjadi perApril 2017, 44\% diantaranya dikaitkan dengan aktivitas illegal dimana jumlah pengguna yang terlibat sekitar $25 \%$ dari seluruh user di dunia atau sekitar 24 juta user. $^{21}$ Jumlah transaksi diperkirakan mencapai 36 juta transaksi dengan rata rata nilai tukar US $\$ 72$ miliar setiap tahunnya.

Serangan malware sebenarnya bukan merupakan jenis kejahatan baru, namun dengan adanya perkembangan teknologi, para hacker menggunakan Bitcoin sebagai tebusan terhadap sistem. Dalam penggunaannya sebagai tebusan, ada dua fungsi utama dari Bitcoin yang dapat diperoleh oleh para hacker

\footnotetext{
${ }^{20}$ CipherTrace Cryptocurrency Intelligence. Cryptocurrency Anti Money Laundring Report .CipherTrace. 2018

${ }^{21}$ Ibid.
} 
yaitu sebagai tebusan dan investasi. Para korban harus menukarkan sejumlah mata uang fiat untuk memperoleh sejumlah Bitcoin yang diminta oleh para hacker. Kemudian para hacker dapat menggunakan Bitcoin yang didapat sebagai investasi dengan mengikuti trading dipasar exchange. Berdasarkan data dari Statista, jumlah serangan ransomware yang terjadi diseluruh dunia pada tahun 2017 sebanyak 184 juta serangan sedangkan di Tiongkok sendiri pada tahun 2017 telah terjadi serangan sebanyak $5,36 \%$ dari total serangan ransomware didunia. ${ }^{22}$ Berdasarkan data dari CipherTrace sejak tahun 2016, $70 \%$ serangan ransomware ditebus menggunakan Bitcoin dengan besarnya tebusan yang dibayarkan kepada hacker dari tahun 2013 hingga pertengahan 2017 adalah minimal US\$ 12.768.536 (22.967,54 BTC) untuk setiap serangan dengan acuan nilai tukar rata rata US\$ 560/BTC. ${ }^{23}$

Menurut Savona pencucian uang merupakan bentuk kejahatan yang diperbarui oleh para penjahat akibat adanya perkembangan bisnis. ${ }^{24}$ Pencucian uang sendiri dapat dimaknai sebagai suatu upaya untuk menyamarkan asal usul uang atau harta kekayaan hasil tindak pidana melalui berbagai transaksi keuangan agar uang atau hasil kekayaan tersebut tampak seolah olaj berasal dari kegiatan legal/sah. Biasanya pencucian uang difasilitasi oleh uang, rekening luar negeri, atau barang mewah misalnya barang seni, rumah, atau kapal. Menurut FATF dalam menangani kasus pencucian uang, metode pembayaran menjadi faktor yang paling

\footnotetext{
${ }^{22}$ Statista. (2019, January 24). Annual number of ransomware attacks worldwide from 2014 to 2017 (in millions). Retrieved from https://www.statista.com/statistics/494947/ransomw are-attacks-per-year-worldwide/.

23 CipherTrace Cryptocurrency Intelligence, Loc.Cit.

24 Savona, E. Organised crime numbers. Global Crime, 1-9. 2014.
}

penting dalam skema pencucian uang. ${ }^{25}$ Seiring dengan perkembangan teknologi, para pelaku pencuci uang lebih memilih menggunakan cryptocurrency khususnya Bitcoin karena adanya konsep anonymous dalam skema Bitcoin, selain itu Bitcoin dianggap memiliki nilai tukar yang paling tinggi dibandingkan dengan cryptocurrency. Berdasarkan laporan dari CipherTrace, bahwa dari 20 crypto market dengan volume trading teratas, $97 \%$ Bitcoin hasil kriminal langsung dialirkan kedalam uang fiat melalui pasar exchanger di negara para pelaku berada khususnya dinegara negara yang tidak memiliki regulasi khusus mengenai Anti Money Laundring menggunakan cryptocurrency, sedangkan apabila dinegara yang memiliki regulasi khusus tersebut para pelaku biasanya melakukan pembayaran tidak langsung dengan menukar cryptocurrency jenis lainnya. ${ }^{26}$ Membandingkan laporan dari Cipher Trace tahun 2017 dan tahun 2018, jumlah cryptocurrency yang terlibat dengan money laundring meningkat, pada tahun 2017 terlapor sebesar US \$ 266 juta sedangkan pada 2018 sebesar US \$ 1,2 miliar dimana Bitcoin mendominasi transaksi rata rata lebih dari 52\% setiap tahunnya dibandingkan dengan semua cryptocurrency yang ada. ${ }^{27}$ Hingga saat ini belum dapat ditemukan statistik mengenai negara negara mana saja yang terlibat dengan money laundring menggunakan cryptocurrency khususnya Bitcoin. Terlepas dari hal tersebut kemungkinan besar disetiap negara yang menggunakan cryptocurrency khususnya Bitcoin memiliki resiko digunakan sebagai media money laundring.

Tindakan ilegal selanjutnya yang memiliki potensi besar dalam penggunaan Bitcoin adalah terorisme. Menurut Parlemen $\mathrm{EU}$, para aktor terorisme dapat digolongkan kedalam beberapa kategori diantaranya aktor kompleks, pelaku tunggal, jaringan afiliasi, organisasi komando, pengendali wilayah dan

\footnotetext{
${ }^{25}$ FATF . Virtual Currencies Key Definitions and Potential AML/CFT Risks. Paris: FATF. 2014

${ }^{26}$ CipherTrace Cryptocurrency Intelligence, Loc.Cit. ${ }^{27}$ Ibid.
} 
pengumpul dana. ${ }^{28}$ Berkaitan dengan pengumpulan dana, para terorisme dapat dikategorikan kedalam tiga kategori yaitu pengumpul dana, pemindah dana, dan penyimpan dana. Fasilitas P2P pada jaringan Bitcoin memberikan keuntungan bagi para pelaku terorisme karena kecil kemungkinan untuk dilakukan pelacakan transaksi. Selain itu, pengumpulan dana dalam bentuk cryptocurrency khususnya Bitcon akan memberikan keuntungan yang lebih untuk dapat menutup segala kebutuhan terorisme melalui trading yang memungkinkan para pelaku untuk mendapatkan keuntungan. Potensi penggunaan Bitcoin sebagai pendanaan aksi terorisme diperkuat dengan adanya beberapa artikel yang dirilis oleh para pendukung terorisme diantaranya Artikel yang berjudul "Bitcoin wa Sadaqat al-Jihad" (Bitcoin dan Amal Fisik Perjuangan Fisik) oleh Ali Sukhri Amin pada tahun 2014, dan Publikasi Online Al-Qaeda Al Haqiqa yang membahas apakah Bitcoin diizinkan oleh hukum syariah dan beberapa alasan yang terkesan merangkul Bitcoin sebagai cara untuk membatasi dukungan ekonomi dengan sistem keuangan barat. Menurut Stalinsky, terdapat sebuah organisasi bernama Anti-Assad AlShadaqah berbasis di Suriah yang secara terbuka menggunakan bitcoin sebagai kampanye penggalangan dana kepada Mujahidin di Suriah berupa senjata, bantuan keuangan, dan proyek lainnya yang berkaitan dengan jihad. ${ }^{29}$ Kampanye tersebut dilakukan melalui media sosial Telegram dengan membagikan wallet address yang dibuka sejak

\footnotetext{
28 European Parliament . Virtual Currencies and Terrorist Financing : Assesing the risk and valuating response. Brussels: Policy Department for Citizens Rights and Constitutional Affairs European Parliament. 2018

${ }^{29}$ Stalinsky, Steven. ( 2019, February 3) Terrorists have been using bitcoin for four years, so what's the surprise? Retrieved from : https://thehill.com/opinion/cybersecurity/377415terrorists-have-been-using-bitcoin-for-four-yearsso-whats-the-surprise.
}

8 November 2017 dan menyatakan bahwa pengiriman dana dapat dilakukan $100 \%$ secara anonim. Melihat hal tersebut dapat disimpulkan bahwa skema Bitcoin juga memungkinkan digunakan sebagai media kampanye online crowd funding bagi terorisme dengan berbagai tujuan misalnya pengadaan senjata dan memfasilitasi perjalanan karena dinilai lebih mudah untuk mentransfer dan lebih sulit dilacak dibandingkan dengan skema perbankan konvensional.

Perkembangan teknologi khususnya internet merupakan suatu trobosan besar abad 20 yang membawa banyak perkembangan bagi semua aspek kehidupan termasuk online market. Berbicara mengenai online market terdapat istilah online dark market yang secara mudahnya dapat dipahami sebagai platform untuk jual beli barang/jasa ilegal. Dalam hal ini, Bitcoin mempunyai peran besar dalam perkembangan online dark market seperti salah satunya adalah Silk Road yang merupakan salah satu online dark market besar yang berhasil ditutup pada tahun 2013 oleh FBI dan Silk Road 2.0 ditutup pada tahun 2014 oleh Europol. Berdasarkan laporan dariFBI telah dilakukan penyitaan Bitcoin sebanyak 173.991 atau senilai lebih dari $\$ 33,6$ juta pada saat itu. $^{30}$ Besarnya angka tersebut bukan merupakan total Bitcoin yang telah terlibat dalam semua transaksi yang ada pada Silk Road. Hal ini disebabkan skema P2P yang menyebabkan fitur anonimitas dapat memungkinkan transaksi dilakukan secara aman.

Dari penjelasan penjelasan diatas dapat disimpulkan bahwa skema P2P dan terdesentralisasi pada network Bitcoin mempunyai potensi besar bagi penggunaan Bitcoin sebagai media pendanaan pendanaan tindakan ilegal. Meskipun dapat dilakukan

30 FBI . Manhattan U.S. Attorney Announces Seizure of Additional \$28 Million Worth of Bitcoins Belonging to Ross William Ulbricht, Alleged Owner and Operator of "Silk Road" Website . New York: FBI New York Press Office. 2013 
pelacakan dengan menggunakan perhitungan algoritma tertentu, namun hal tersebut memiliki persentase kecil karena besarnya blockchain Bitcoin. Hal tersebutlah yang mendorong pemerintah Tiongkok untuk melakukan pelarangan transaksi ICO khusunya Bitcoin karena Bitcoin memiliki dominitas terbesar dibandingkan cryptocurrency lainnya pada saat ini.

Faktor terakhir yang melatar belakangi perintah larangan transaksi berbasis ICO dan penutupan pasar BTCC oleh pemerintah Tiongkok adalah penggunaan listrik yang berlebih. Berdasarkan data dari Statista, Tiongkok merupakan salah satu negara dengan biaya listrik terendah didunia. ${ }^{31}$ Berdasarkan data dari Buy Bitcoin World Wide, 70\% pabrik tambang Bitcoin berlokasi di Tiongkok. ${ }^{32}$ Rata rata harga listrik untuk industri dan komersial sepanjang tahun 2017 adalah 0,54 Yuan/ kWh hingga 0,61 Yuan/ $\mathrm{kWh}$ atau sekitar US \$ 0,08 / kWh hingga US \$0,09 / kWh. Sedangkan banyaknya Bitcoin yang dihasilkan berdasarkan laporan dari National Business Daily (Daily, 2017) pada salah satu perusahaan tambang Bitcoin yang bernama TanJia WangLuo, dalam sehari dapat menghasilkan 27 coin dengan biaya listrik sebesar US $\$ 1000$. Sedangkan banyak pabrik tambang Bitcoin yang namanya tidak terdaftar secara resmi. Komisi Ekonomi dan Informasi sebelumnya menyatakan bahwa operasi pertambangan tidak memberikan kontribusi apa pun bagi perekonomian kawasan selain mengkonsumsi volume listrik yang melonjak. Oleh karena itu pemerintah Tiongkok melarang adanya penambangan Bitcoin, transaksi ICO, serta penutupan pasar pertukaran BTCC.

31 Global electricity prices in 2018, by select country (in U.S. dollars per kilowatt hour). ( 2019 , February 5) Retrieved from: https://www.statista.com/statistics/263492/electricit y-prices-in-selected-countries/.

${ }^{32}$ Buy Bitcoin World Wide. (2019, February 4). Retrieved from: (https://www.buybitcoinworldwide.com/mining/po ols/)
Dari ketiga faktor yang telah dijelaskan diatas, dapat dipahami bahwa pelarangan ICO dan penutupan pasar BTCC sebenarnya merupakan sebuah ancaman tersendiri terhadap pemerintah yang dapat mempengaruhi perekonomian Tiongkok, terlebih jika kekhawatiran akan meletusnya bubble investation benar benar terjadi. Perekonomian Tiongkok akan menurun secara tidak langsung karena banyaknya masyarakat Tiongkok baik sebagai trader, miner, maupun investor yang kehilangan Yuan mereka. Selain itu, pemerintah juga ingin mengurangi kemungkinan adanya tindakan pencucian uang atau kejahatan lain dinegaranya, berkaitan dengan konsep P2P yang dimiliki oleh ICO khususnya Bitcoin. Berkaitan dengan faktor yang ketiga, dapat dilihat bahwa meskipun bisnis mining memang sangat menghasilkan, namun ICO (Bitcoin) bukanlah salah satu subjek ekonomi yang dapat dikenakan pajak. Oleh karenanya, pemerintah merasa dirugikan, karena besarnya pendapatan miner tidak sebanding dengan pengeluaran biaya listrik, sedangkan pemerintah tidak mendapat apa apa.

Selain faktor faktor yang telah dijelaskan sebelumnya, terdapat sebuah fenomena bahwa berdekatan dengan pelarangan ICO dan penutupan BTCC, Pemerintah justru memberikan pernyataan mengenai rencana pengembangan national cryptocurrency sendiri. Berkaitan dengan faktor yang telah dijelaskan sebelumnya, mendorong munculnya sebuah argumen bahwa rencana pengembangan national cryptocurrency sendiri tersebut merupakan upaya penciptaan hegemoni baru oleh Tiongkok dalam rangka penyeimbangan Amerika dalam ekonomi global yang dilihat dari konsep hegemoni yang dijelaskan pada subbab berikutnya.

\section{Upaya Hegemoni Tiongkok dalam Ekonomi Global}

Paska Perang Dingin, sistem internasional terbentuk menjadi unipolar dimana terdapat sebuah negara dengan 
hegemoni terbesar dan merupakan satu satunya great power didunia mempunyai pengaruh besar dalam menentukan tindakan dari negara negara lainnya. Berbeda dengan Perang Dingin, paska Perang Dingin diwarnai dengan adanya non militer war untuk berusaha mengimbangi hegemoni sebuah negara tersebut. ${ }^{33}$ Menurut Pape, tindakan tindakan non militer tersebut salah satunya dapat dilakukan melalui empat cara yaitu penolakan akses terhadap wilayah, diplomasi, memperkuat ekonomi, dan memberikan tanda atau signal terhadap pemimpin negara unipolar akan adanya tindakan balancing dengan membentuk koalisi atau institusi internasional. ${ }^{34}$ Dalam penelitian ini, akan digunakan poin ketiga dari definisi Pape mengenai soft balancing yaitu memperkuat ekonomi untuk menganalisis kebijakan pemerintah Tiongkok. Berikut ini adalah faktafakta yang menunjukkan upaya penciptaan hegemoni baru dalam bidang ekonomi berkaitan dengan dunia cryptocurrency yang dilakukan oleh Tiongkok untuk memperkuat ekonominya dalam upaya penyeimbangan terhadap Amerika:

Pertama, Tiongkok merupakan negara dengan jumlah penduduk terbesar didunia, dimana sebagian besar penduduknya telah mengenal teknologi sehingga dalam transaksi sehari hari lebih banyak digunakan digital payment baik e-money atau virtual currency lainnya sehingga Tiongkok saat ini telah menyandang gelar sebagai negara dengan pasar terbesar untuk cashless payment. Dalam transaksi sehari hari, biasanya masyarakat Tiongkok menggunakan telepon genggam mereka untuk melakukan pembayaran baik transaksi di supermarket atau hanya sekedar membayar transportasi umum. Berdasarkan data dari PI 92\% masyarakat Tiongkok dikota kota besar di Tiongkok telah menggunakan media cashless payment untuk melakukan

\footnotetext{
${ }^{33}$ Hadiwinata, Bob Sugeng. Loc. Cit.

${ }^{34}$ Pape, Robert A. Loc.Cit.
}

transaksi sehari hari. ${ }^{35}$ Dari hal tersebut dapat dilihat bahwa masyarakat Tiongkok telah familiar dengan teknologi.

Selain itu, jumlah penduduk Tiongkok yang besar sebenarnya memberikan keuntungan tersendiri bagi para pemilik modal. Berkaitan dengan standar kehidupan masyarakatnya, Tiongkok relatif dianggap miskin. Oleh karenanya, banyak para pelaku usaha yang mendirikan pabrik di Tiongkok agar biaya produksi dapat ditekan karena upah tenaga kerja yang murah. Sehingga, Tiongkok memiliki produk dengan harga yang lebih murah yang dapat meningkatkan nilai ekspor nya. Tiongkok sendiri telah menduduki negara pengekspor terbesar, dimulai 2016 dimana negara penerima terbesar adalah Amerika.

Kedua, Tiongkok merupakan negara dengan jumlah perputaran Bitcoin terbesar didunia pada 2013-2017. Seperti yang telah dijelaskan sebelumnya bahwa meskipun Bitcoin hanya merupakan network yang dijalankan secara terdesentralisasi dan bukan berasal dari sebuah negara, tetap saja Bitcoin merupakan sebuah nilai yang akan memiliki nilai ketika banyak user yang percaya dan menggunakan Bitcoin tersebut baik sebagai media investasi atau media transaksi. Beralihnya masyarakat dari uang fiat sebuah negara terhadap cryptocurrency merupakan awal tanda ketidakpercayaan masyarakat terhadap pemerintah termasuk terhadap nilai dari uang fiat negaranya sendiri. Termasuk pula ketika banyak masyarakat Tiongkok yang menggunakan Bitcoin baik sebagai media transaksi atau media investasi, hal tersebut memberikan ancaman tersendiri bagi pemerintah Tiongkok. Selain karena berbagai alasan yang telah dijelaskan pada sub judul sebelumnya, berjalannya network Bitcoin secara terdesentralisasi membuat pemerintah Tiongkok tidak memiliki kontrol sama sekali terhadap segala transaksi Bitcoin dan hal

\footnotetext{
35 Pinguin Intellegence. 2017 We Chat User and Business Ecosystem Report . 2017
} 
tersebut merupakan sebuah ancaman tersendiri terhadap Yuan sebagai mata uang Tiongkok. Oleh karena itu, setelah pelarangan transaksi ICO khususnya Bitcoin dilakukan oleh pemerintah Tiongkok, pemerintah kembali memberikan pernyataan berupa rencana pengembangan national cryptocurrency sendiri untuk dapat mempertahankan nilai Yuan. Sebagaimana yang telah dijelaskan sebelumnya bahwa dalam dunia ICO dan IPO terdapat sebuah poin penting yang membedakan keduanya, yaitu harga indeks IPO dapat dipengaruhi oleh sebuah kebijakan yang dikeluarkan pemerintah negara tertentu karena kebijakan pemerintah berkaitan dengan industri atau perdagangan biasanya akan berpengaruh secara langsung terhadap bursa saham. Sedangkan pada dunia ICO, kebijakan pemerintah tersebut baik berkaitan dengan perdagangan atau keadaan politik negara yang kacau atau perang sekalipun tidak akan memengaruhi sama sekali terhadap nilai tukar dunia ICO, karena sekali lagi bahwa cryptocurrency dijalankan secara terdesentralisasi tanpa ada pihak ketiga yang mengintervensi.

Ketiga, revolusi sistem ekonomi dari tertutup menjadi terbuka, menyebabkan Tiongkok merupakan salah satu negara sebagai aktor utama dalam dunia IPO mengingat Tiongkok merupakan rising country dengan jumlah industri yang selalu berkembang setiap tahunnya. Hal tersebut dibuktikan dengan maraknya produk produk Tiongkok yang mempunyai pasar hampir disetiap negara. Berdasarkan data dari Focus Economics, indeks produksi industri dan tingkat pertumbuhan rata-rata tahunan Tiongkok dari Mei 2016 hingga Mei 2018 rata rata mengalami peningkatan sebesar $6,1 \%$ hingga $6,8 \% .^{36}$ Berkaitan dengan pendanaan

\footnotetext{
${ }^{36}$ Focus Economics. (2019, February 20) China Industry May 2018. Retrieved from: https://www.focuseconomics.com/countries/china/news/industry/man ufacturing-activities-drag-on-industrial-productiongrowth-in-may
}

perindustrian, perkembangan teknologi membuat IPO sebagai crowd funding berkembang menjadi ICO dengan menggunakan teknologi berbasis blockchain. Terlepas dari persebaran penggunaan cryptocurrency dalam sebuah negara, Tiongkok mempunyai pengaruh besar dalam menentukan nilai tukar cryptocurrency khususnya Bitcoin sejak 2013 hingga september 2017 yang rata rata selalu mengalami pengingkatan. Hal tersebut ditambah dengan adanya industri mining pool Bitcoin yang berkembang pesat di Tiongkok sepanjang tahun 2015 hingga 2017 menyebabkan perputaran Bitcoin di Tiongkok menjadi presentase terbesar diseluruh dunia. Pada September 2017, pemerintah Tiongkok mengeluarkan kebijakan pelarangan transaksi ICO - cryptocurrency khususnya penggunaan Bitcoin. Terdapat beberapa faktor yang melatarbelakangi pemerintah Tiongkok untuk melakukan pelarangan tersebut sebagaimana yang telah dijelaskan sebelumnya. Akibat dari kebijakan tersebut, Bitcoin mengalami penurunan yang sangat signifikan dibandingan ketika Tiongkok mempunyai andil dalam perputaran pasar cryptocurrency tersebut. Besarnya pengaruh Tiongkok dalam menentukan nilai tukar cryptocurrency tersebut dibuktikan melalui grafik berikut: 


\section{Gambar 3. Grafik persebaran Bitcoin dalam beberapa Cryptomarket di Dunia}

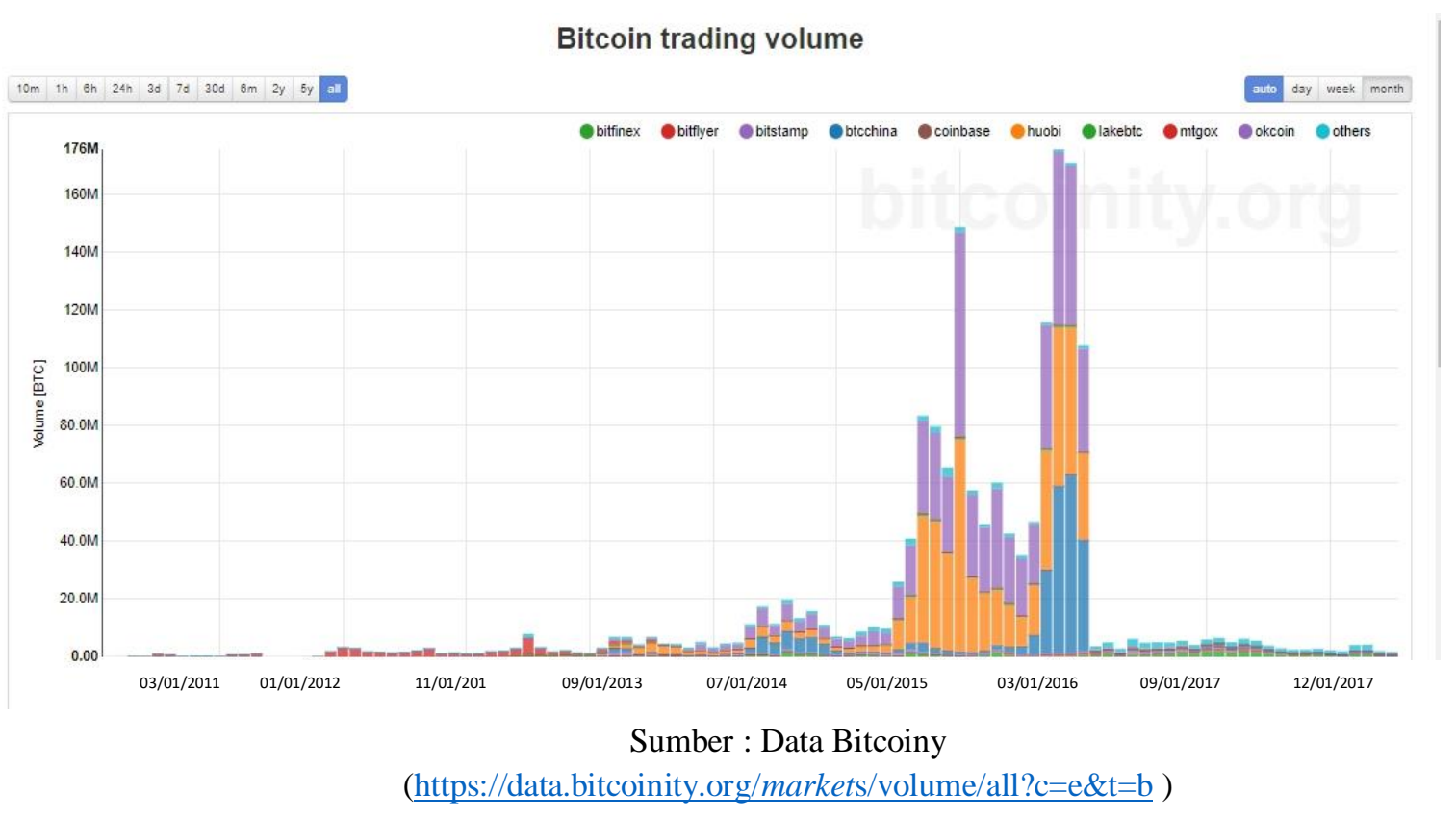

Grafik diatas merupakan persebaran Bitcoin sebagai cryptocurrency dengan nilai capital market terbesar hingga saat ini yang diperjual belikan melalui cryptomarket. Terdapat setidaknya tiga cryptomarket besar yang termasuk kedalam grafik tersebut dimana tiga cryptomarket tersebut berasal dari Tiongkok, yaitu BTTChina, Huobi, dan OkCOin. Dua dari tiga cryptomarket tersebut juga termasuk dalam tiga besar peringkat cryptomarket dengan perputaran Bitcoin tertinggi didunia. Dari grafik diatas dapat dilihat bahwa mulai tahun 2013, perputaran dan nilai Bitcoin semakin naik dari tahun ke tahun dimana dari rentang 2015- 2017 merupakan kisaran tahun Bitcoin memiliki nilai tukar tertinggi sepanjang sejarah. Selain itu, rentang waktu tersebut bertepatan dengan waktu Tiongkok menjadi negara dengan perputaran Bitcoin terbesar didunia. Sedangkan diakhir tahun 2017, pada grafik tersebut mengalami penurunan. Hal ini dikarenakan adanya kebijakan pelarangan transaksi ICO oleh pemerintah Tiongkok, sehingga para investor Bitcoin di Tiongkok mulai meninggalkan Bitcoin sebagai media investasi meskipun tidak semua investor secara langsung melepas semua Bitcoin yang mereka miliki. Oleh karena itu, dari semua penjelasan diatas dapat disimpulkan bahwa Tiongkok merupakan negara yang mempunyai pengaruh terhadap perekonomian global berkaitan dengan penggunaan cryptocurrency sebagai media crowd funding (ICO) dan rising economy country yang secara besar kecilnya perindustrian Tiongkok mempunyai pengaruh tersendiri melalui peralihan dunia IPO menjadi ICO dalam tujuannya "crowd funding" bagi perusahaan perusahaan.

Keempat, berkaitan dengan rencana pengembangan national cryptocurrency, hal tersebut duumumkan oleh Pemerintah Tiongkok melalui sebuah artikel online yang menganalisa pentingnya mengembangkan national cryptocurrency secara resmi pada Oktober 2017 melalui PBOC. Sebelumnya pemerintah Tiongkok telah melakukan pelarangan secara keras terhadap transaksi berbasis ICO khususnya Bitcoin yang mempunyai pasar besar di Tiongkok. Pasca pelarangan transaksi ICO khususnya Bitcoin, dunia blockchain di Tiongkok tidak langsung padam begitu saja. Para investor tech giants seperti Baidu, Tencent, dan Alibaba mulai beralih ke teknologi blockchain yang lain yang tidak hanya bergerak dalam ranah pembayaran saja misalnya game atau aplikasi yang 
mempunyai credit yang dapat digunakan untuk melakukan transaksi produk mereka lainnya. Melihat besarnya animo masyarakat, Presiden $\mathrm{Xi}$ Jin Ping mendukung adanya rencana pengembangan blockchain tersebut dan memiliki pandangan positif terhadap potensi dunia blockchain. Selain itu, PBOC menyatakan bahwa pemerintah sedang berupaya melakukan pengembangan national cryptocurrency yang berbasis blockchain. Bahkan pemerintah Tiongkok telah bekerjasama dengan OKCoin sebagai pasar trading yang nantinya dapat digunakan sebagai media trading keluar pasar Tiongkok. Rencana pengembangan national cryptocurrency ini didukung oleh pernyataan Presiden Xi Jin Ping dalam pidatonya pada acara the $19^{\text {th }}$ Academician Meeting of the Chinese Academy of Sciences alongside the $14^{\text {th }}$ Academician Meeting of the Chinese Academy of Engineering pada 28 Mei 2018 yang mengatakan:

"Sejak abad ke-21 dimulai, inovasi ilmiah dan teknologi global telah memasuki periode aktivitas intensif yang belum pernah terjadi sebelumnya. Putaran baru revolusi ilmiah, teknologi dan perubahan industri merekonstruksi peta inovasi global dan membentuk kembali struktur ekonomi global. Generasi baru teknologi informasi yang diwakili oleh kecerdasan buatan, informasi kuantum, komunikasi seluler, internet, dan blockchain mempercepat terobosan dalam aplikasi dan telah melahirkan bidang ilmu kehidupan baru yang diwakili oleh biologi sintetis, genetika, kecerdasan buatan, dan obat regeneratif."

Pemerintah Tiongkok mengklaim bahwa adanya upaya pengembangan national cryptocurrency bertujuan untuk mencapai salah satu poin the $13^{\text {th }}$ Five-Year Plans for Economic and Social Development of The People's Republic of China (2016-2020) yaitu menciptakan cyber economy. Selain itu adanya national cryptocurrency diharapkan akan memberikan manfaat seperti mengurangi biaya yang dikeluarkan dalam penerbitan sebagaimana dalam uang fiat, peningkatan transparansi dan kenyamanan transaksi ekonomi, adanya kontrol bank sentral terhadap jumlah dan sirkulasi sehingga dapat meminimalisir pecahnya bubble investation pemberantasan penggelapan pajak, pencucian uang dan tindakan ilegal, serta memudahkan transaksi lintas batas negara. Sejak keluarnya pernyataan tersebut, belum ada pengumuman resmi mengenai cryptocurrency apakah yang akan dijadikan sebagai national cryptocurrency oleh pemerintah Tiongkok. Namun hingga Januari 2019 pemerintah Tiongkok telah memberikan dukungan dan perhatian terhadap beberapa perusahaan besar yang bergerak dalam bidang blokchain seperti NEO, QTUM, dan Ve-Chain. dengan mengucurkan dana sebagai dana riset sebesar US\$ 1,6 miliar. Berkaitan dengan hal tersebut, penulis akan berfokus pada NEO sebagai salah satu cryptocurrency berbasis teknologi blockchain yang mendapat dukungan dari Pemerintah Tiongkok. NEO merupakan cryptocurrency asal Tiongkok yang mempunyai skema semi desentralisasi. Berbeda dengan cryptocurrency lainnya, dalam hal ini terdapat pihak pihak yang dapat mengetahui identitas dari setiap user karena adanya fitur digital identity. Fitur tersebut diciptakan oleh pengembang NEO dalam rangka mendukung program Pemerintah Tiongkok untuk menciptakan cyber economy yang transparan.

Pengembangan NEO sebagai sebuah platform yang dapat diklaim sebagai national cryptocurrency merupakan langkah lanjutan dari the $13^{\text {th }}$ Five Year Plans (2016- 2020) Tiongkok dimana salah satu poinnya adalah menciptakan cyber economy. Hal tersebut direalisasikan melalui perencanaan pengembangan blockchain oleh pemerintah Tiongkok. Terdapat beberapa keuntungan dalam penggunaan teknologi blockchain sebagai media dalam berbagai aspek khususnya dalam dunia bisnis, diantaranya: teknologi blockchain memungkinkan verifikasi setiap transaksi secara otomatis melalui minimal 6 orang miner tanpa bergantung pada 
pihak ketiga seperti bank atau penyedia jasa lainnya. Selanjutnya, Setiap transaksi yang telah terverifikasi akan terdata secara otomatis kedalam blockchain yang merupakan ledger besar yang dapat dilihat oleh siapa saja dimana blockchain tersebut bersifat imutable sehingga data yang telah tercatat tidak dapat diubah atau dihapus. Keuntungan selanjutnya adalah blockchain dijalankan dengan perlindungan algoritma kriptografi tertentu, sehingga transaksi bersifat aman dari hacker. Selanjutnya sebelum sebuah transaksi tercatat dalam blockchain, transaksi tersebut terlampir dalam block block yang saling berkaitan untuk membentuk blockchain. Transaksi akan tercatat dalam blockchain setelah transaksi terverifikasi dengan kepercayaan maksimum. Transaksi transaksi yang telah tercatat dalam blockchain dicatat dalam urutan kronologis, dimana setiap transaksi dilampirkan kapan waktu seorang user tersebut mendapat nilai dan kapan nilai tersebut ditransaksikan sehingga dalam blockchain catatat transaksi lebih rapi dan tertata. Jaringan blockchain yang dijalankan secara terdesentralisasi akan membuat antar jutaan komputer didunia saling terhubung satu sama lain sehingga sulit untuk dilakukan peretasan dan pengubahan data yang tercantum pada blockchain. Selain itu setidaknya terdapat tiga tambahan fitur pada teknologi NEO yaitu digital identity, digital sertificate, dan smart contract. Digital Identity merupakan fitur dari platform NEO yang mengharuskan para usernya untuk melakukan verifikasi digital, baik berupa sidik jari, sensor mata, tekstur wajah ataupun otentifikasi digital media lainnya. Digital Sertificate merupakan fitur dari platform NEO yang merupakan jaminan hukum yang diberikan oleh para developer NEO beserta pemerintah Tiongkok kepada para user platform NEO dengan harapan agar user dapat lebih percaya terhadap aset yang didigitalkan melalui platform NEO. Sedangkan Smart Contract adalah fitur dari platform NEO yang memungkinkan para developer dari berbagai negara dengan kemampuan bahasa pemrograman yang berbeda dapat ikut mengembangkan platform
NEO menjadi platform yang memiliki user dari berbagai macam negara pula, karena perlu diketahui bahwa platform NEO tidak hanya berbatas pada cryptocurrency saja melainkan sebuah platform yang terdiri dari berbagai macam fokus dan fungsi yang saling terintegrasi.

NEO merupakan salah satu cryptocurrency yang saat ini telah memiliki pasar besar dalam dunia ICO. Hal ini dibuktikan dengan nilai capitalmarket NEO yang selalu menduduki 20 besar ranking berdasarkan Coin Market Cap. ${ }^{37}$ Meskipun nilai NEO belum sebesar perputaran Bitcoin, tetapi NEO merupakan cryptocurrency yang memang berasal dari Tiongkok. Selain itu adanya fitur digital identity, digital sertificate, dan smart contract membuat pemerintah Tiongkok mempunyai akses tersendiri terhadap setiap node dalam jaringan blockchain NEO. Dengan kata lain, dapat dikatakan bahwa jaringan NEO sebenarnya tidak dijalankan secara murni dengan terdesentralisasi melainkan semi terdesentralisasi. Sedangkan melihat Gambar 4 statistik persebaran NEO berdasarkan lokasi negara cryptomarket, dapat dilihat bahwa NEO benar benar telah memiliki sasaran pasar yang luas dan hampir mencakup semua negara yang memang terbuka terhadap transaksi ICO.

\footnotetext{
37 All Cryptocurrencies | Coinmarketcap. (2019, January

$10)$.

Retrieved

from
} 
122 Pungki Retnowati dan Ika Riswanti Putranti | Bitcoin vis a vis NEO: Upaya Tiongkok menuju Penyeimbang Kekuatan Ekonomi Amerika Serikat dalam Kacamata Hegemoni dan Soft Balancing

\section{Gambar 4. Statistik NEO Exchange berdasarkan Cryptomarket}

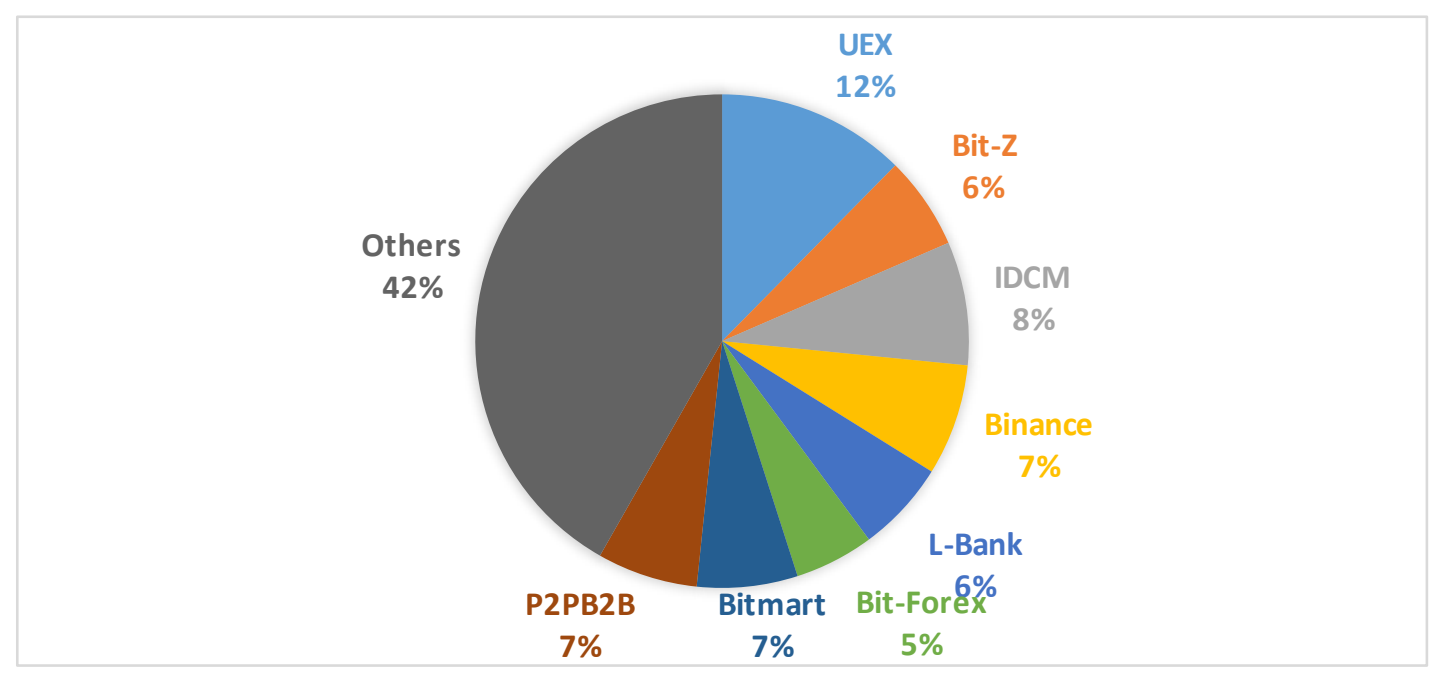

\begin{tabular}{l|l}
\hline \multicolumn{1}{c|}{ Cryptomarket } & \multicolumn{1}{c}{ Based Country } \\
\hline UEX & Singapore, New York, San Fransisco, Taipe \\
\hline Bit-Z & $\begin{array}{l}\text { Hongkong, Singapore, Jepang, Korea Selatan, } \\
\text { Prancis, Australia, Amerika Serikat, Vietnam, Rusia, } \\
\text { Denmark }\end{array}$ \\
\hline IDCM & $\begin{array}{l}\text { Dubai, Korea Selatan, Vietnam, Amerika Serikat, } \\
\text { Thailand, Australia, Hongkong, Makau, Norwegia, } \\
\text { Kamboja, Prancis, Jepang }\end{array}$ \\
\hline Binance & $\begin{array}{l}\text { Asia, Jerman, Amerika Serikat (California), Vietnam, } \\
\text { Turki, Uganda, Inggris, Malta, Filipina, Rusia, India, } \\
\text { Prancis, Korea Selatan, Singapore }\end{array}$ \\
\hline B-Bank & Hongkong, Tiongkok \\
\hline Bitmart & $\begin{array}{l}\text { Seychelles, Singapore, Korea Selatan, Hongkong, } \\
\text { Philipina, Malaysia, Jepang }\end{array}$ \\
\hline P2PB2B & $\begin{array}{l}\text { Cayman Islands, Tiongkok, Amerika Serikat, Korea } \\
\text { Selatan }\end{array}$ \\
\hline
\end{tabular}


Hal tersebut didukung dengan adanya kemampuan smart contract pada network NEO yang memungkinkan para developer dari berbagai negara dengan berbagai latar belakang dan kemampuan bahasa pemrograman yang berbeda, dapat turut serta mengembangkan platform NEO melalui DApps. DApps merupakan Decentralized Applications dimana aplikasi aplikasi yang dikembangkan oleh para developer dari berbagai negara mempunyai fungsi dan tujuan masing masing, misalnya booking, gaming, dan trading. Dalam menjalankan fungsinya, para developer memanfaatkan platform NEO dan mengintegrasikannya dengan platform NEO sehingga dalam media pembayaran dan transaksi yang dibutuhkan akan secara otomatis terhubung dengan blockchain NEO. Semakin banyak user sebuah DApps maka jumlah user NEO akan semakin meningkat pula. Semakin meningkat jumlah user NEO maka akan meningkat pula capital market NEO.

Dari semua penjelasan diatas dapat dilihat bahwa NEO merupakan realisasi dari the $13^{\text {th }}$ Five-Year Plans for Economic and Social Development of The People's Republic of China (2016-2020) dimana salah satu poinnya adalah menciptakan cyber economy. Semakin banyak user NEO yang tersebar hampir diseluruh negara, maka ekonomi Tiongkok akan mengalami perkuatan karena adanya pergeseran fungsi dari IPO menjadi ICO diluar negara Tiongkok. Dimana tindakan memperkuat ekonomi dalam hal ini melalui teknologi blockchain oleh pemerintah Tiongkok merupakan bagian dari upaya soft balancing pemerintah Tiongkok terhadap Amerika sebagai negara unipolar. Sebagaimana telah dijelaskan sebelumnya bahwa negara unipolar memberikan ancaman tersendiri terhadap negara negara non unipolar termasuk Tiongkok melalui kebijakan protection yang menyebabkan terjadinya perang dagang. NEO sendiri juga memiliki potensi untuk menjadi national cryptocurrency bagi Tiongkok sebagai modal Tiongkok untuk menciptakan hegemony baru dalam dunia cryptocurrency, meskipun nilai tukar NEO murni ditentukan oleh mekanisme pasar. Hal ini disebabkan karena adanya akses informasi yang dimiliki oleh pemerintah Tiongkok terhadap data dari setiap user NEO. Selain dalam dunia cryptocurrency, NEO juga memiliki potensi untuk menjadi global currency sebagaimana Dollar menjadi global currency yang digunakan hampir diseluruh negara. Melalui fitur fitur yang diusung network NEO, nantinya setiap transaksi yang dilakukan khususnya transaksi antar negara melalui platform NEO akan lebih mudah, lebih murah, lebih efisien, dan tidak bergantung pada pihak ketiga berbeda dengan sistem perbankan sebagimana telah dijelaskan sebelumnya.

\section{Soft Balancing Ekonomi Tiongkok terhadap Amerika Serikat}

Amerika merupakan satu satunya negara great power yang mempunyai banyak pengaruh terhadap negara negara lain sejak berakhirnya Perang Dingin, dimana salah satu bidangnya adalah ekonomi. Seperti yang kita ketahui bahwa USD merupakan mata uang yang mempunyai pengaruh besar dalam perekonomian global dan telah bertahan selama beberapa dekade. Menurut Seetharaman, saat ini Renminbi Tiongkok mulai menantang USD dalam keuangan internasional. ${ }^{38}$ Hal tersebut dibuktikan dengan fakta bahwa USD dalam mata uang cadangan global menurun. Meskipun demikian Renminbi belum dapat bersaing secara kuat karena dianggap tidak memiliki prasyarat utama untuk menjadi mata uang global yaitu konversi gratis dan penuh, selain itu nilai tukar USD dianggap lebih stabil dan Amerika merupakan negara yang memiliki pengaruh dominasi yang besar dalam dunia internasional. Jika CNY ingin mendominasi maka harus dibentuk sendiri

\footnotetext{
${ }^{38}$ Seetharaman, A, and A.S Saravanan, Nitin Patwa, Jigar Mehta. Impact of Bitcoin as a World Currency. Accounting and Finance Research, 1-17. 2017
} 
mata uang regional yang dapat menjadi langkah pertama untuk menjadi global currency. ${ }^{39}$ Sebagaimana yang telah dijelaskan sebelumnya bahwa salah satu penyebab turunnya nilai USD sebagai mata uang cadangan global dikarenakan adanya kebijakan protection yang dilakukan oleh Donald Trump, dimana kebijakan protection tersebut membuat perang dagang terjadi secara besar besaran karena pemerintah Amerika memberikan kenaikan terhadap bea masuk kepada barang barang impor sehingga barang barang impor dari luar Amerika dapat dikurangi. Hal tersebut tentunya membuat negara negara pengekspor merasa dirugikan karena mereka tidak dapat menembus pasar Amerika seperti sebelumnya. Adanya perang dagang tersebut membuat para investor dari luar Amerika menarik saham mereka, sehingga indeks saham di Amerika menjadi turun. Akibatnya masyarakat di Amerika mengalami penurunan kepercayaan terhadap pemerintah mereka. Sehingga untuk tetap mempertahankan nilai kekayaan mereka, mereka beralih menggunakan ICO sebagai media berinvestasi.

Berkaitan dengan adanya perkembangan teknologi, cryptocurrency memberikan potensi bagi suatu negara untuk dapat menjadi penyeimbang Amerika sebagai negara yang memiliki hegemon secara ekonomi. Dobija menjelaskan bahwa dengan adanya kemajuan teknologi, nantinya akan ada dimensi baru yang ditambahkan dalam perdebatan global currency dimana masa depan akan terbebas dari uang kertas dan hanya akan ada satu unit saja yang akan maju sebagai global currency. ${ }^{40}$ Bitcoin sendiri dapat menjadi ancaman serius bagi USD karena adanya skema Bitcoin yang mudah digunakan dibandingkan dengan USD.

\footnotetext{
${ }^{39}$ Hokroh, M.A. Examining the Chinese Exchange Rate Reform and the Possibility of the Chinese Yuan Becoming a Regional Trade Currency. Research in Applied Economics. 2013

${ }^{40}$ Dobija, M. The Global Currency Area a Way to Constructively End the Era of Reserve Currency. Modern Economy . 2014
}

Selain itu, nilai tukar Bitcoin yang hanya ditentukan oleh mekanisme pasar tanpa ada pengaruh dari pemerintah akibat $\mathrm{P} 2 \mathrm{P}$ network menjadikan potensi ancaman terhadap USD semakin besar melihat besarnya penggunaan Bitcoin dalam transaksi transaksi yang dilakukan oleh masyarakat Amerika Serikat melalui merchant-merchant baik secara online atau konvensional. Hal tersebut disebabkan oleh menurunnya tingkat kepercayaan masyarakat terhadap suatu nilai dalam hal ini Dollar akibat dari adanya kebijakan protection yang mengakibatkan adanya perang dagang yang berimbas pada pergeseran peran IPO menjadi ICO untuk mempertahankan suatu nilai yang dimiliki oleh seseorang.

Berkaitan dengan adanya sistem internasional unipolar, sistem tersebut membuat negara unipolar bersikap semaunya sesuai ego dan kepentingannya. Pada dasarnya sikap yang dilakukan sebuah negara merupakan cerminan sikap dari manusianya dikarenakan negara merupakan kumpulan kumpulan dari individu dan berperilaku memperjuangkan kepentingannya sebagaimana yang dijelaskan oleh paradigme realisme. Dalam penelitian ini digunakan konsep soft balancing dan hegemony dimana konsep tersebut merupakan konsep turunan dari teori realisme. Soft balancing merupakan tindakan non militer yang dilakukan oleh negara dalam rangka menyeimbangkan perannya untuk mengurangi ancaman hegemony negara unipolar. Sedangkan hegemony adalah kemampuan sebuah negara untuk dapat mempengaruhi negara lain dalam rangka memperjuangkan kepentingan nasionalnya dengan kemampuan kemampuan komprehensif dimana negara negara lain tidak memilikinya. Tiongkok merupakan negara non unipolar berdasarkan sistem internasional yang telah terbentuk sejak berakhirnya perang dingin. Sedangkan Amerika merupakan negara unipolar yang memiliki kemampuan komprehensif baik dibidang ekonomi, militer, teknologi, sosial budaya sehingga Amerika sering disebut sebagai negara super power. 
Berbekal kemampuan kemampuan yang dimilikinya, Amerika sering mengambil kebijakan yang dapat memberikan ancaman tersendiri bagi negara negara lainnya.

Tiongkok merupakan salah satu negara dengan indeks pertumbuhan ekonomi tercepat dengan rata rata lebih dari 10\% dalam 30 tahun terakhir menjadikan Tiongkok sebagai negara yang mulai dikhawatirkan oleh Amerika sebagai negara super power. Indeks tersebut merupakan gabungan dari beberapa indikator dimana salah satunya adalah kebebasan ekonomi melalui pasar terbuka, termasuk penggunaan cryptocurrency dalam transaksi ICO . Rencana Tiongkok untuk mengembangkan teknologi blockchain melalui project NEO merupakan langkah yang diambil oleh pemerintah Tiongkok sebagai langkah untuk menyeimbangkan Tiongkok dan Amerika Serikat dalam bidang ekonomi. Meskipun nilai tukar NEO belum sebesar Bitcoin, namun NEO merupakan cryptocurrency asal Tiongkok dimana pemerintah Tiongkok memiliki akses terhadap transaksi NEO karena skemanya yang semi desentralisasi. Persebaran NEO melalui cryptomarket cryptomarket yang tersebar hampir diseluruh negara negara besar seperti yang tertera pada gambar 4, dan penggunaan NEO sebagai platform yang terintegrasi melalui DApps yang dikembangkan oleh para developer developer yang tersebar diberbagai penjuru negara.

Selain itu, dimasa depan penggunaan NEO sebagai cryptocurrency yang berkembang menjadi national cryptocurrency akan membawa potensi bahwa NEO akan menjadi global currency, hal ini disebabkan karena perubahan nilai tukar NEO hanya didasarkan pada mekanisme pasar saja sedangkan kebijakan proteksi yang dilakukan oleh Amerika membawa dampak domino bagi negara negara lain termasuk Tiongkok dan menyebabkan para investor beralih dari IPO menjadi ICO. Selain itu, besarnya pengaruh perkembangan perekonomian Tiongkok melalui pasar terbuka, perdagangan, atau industri juga memiliki nilai andil yang besar dalam dunia global. Terlebih Tiongkok memiliki potensi untuk menggunakan NEO sebagai prasyarat media khusus dalam melakukan perdagangan internasional. Hal tersebut tentunya akan semakin memperkuat perekonomian Tiongkok dan membuat Tiongkok semakin berpengaruh dalam perekonomian dan perdagangan secara regional maupun internasional. Hal tersebut sesuai dengan definisi konsep soft balancing dimana memperkuat ekonomi merupakan salah satu komponen dari upaya balancing. Sebagaimana yang kita ketahui bahwa Amerika merupakan negara super power yang terbentuk secara unipolar setelah Perang Dingin selesai, sedangkan Tiongkok merupakan salah satu rising country yang memiliki indeks pertumbuhan ekonomi tercepat didunia. Penggunaan NEO tentunya lebih memiliki manfaat dibandingkan dengan penggunaan Bitcoin, hal ini dikarenakan Bitcoin tidak memiliki nilai tukar yang pasti dan memiliki fitur anonym dimana pemerintah Tiongkok tidak dapat memiliki akses terhadap informasi para usernya. Sedangkan dalam NEO, pemerintah memiliki akses terhadap user dengan adanya fitur digital information. Penggunaan NEO secara luas baik melalui DApps NEO maupun sebagai cryptocurrency membuat Tiongkok memiliki potensi untuk dapat memberikan pengaruh terhadap negara negara lain yang lebih lemah dan mengurangi ancaman hegemony dari negara unipolar. Selain itu, kemampuan ekonomi Tiongkok melalui NEO memiliki potensi menjadikan Tiongkok menjadi hegemony baru menyeimbangi Amerika. Hal ini dikarenakan hingga saat ini Amerika tidak memiliki rencana pengembangan teknologi blockchain sebagaimana yang dilakukan oleh Tiongkok sedangkan nilai Dollar Amerika masih berangsur angsur mengalami penurunan sebagai mata uang cadangan global.

Berdasarkan penjelasan penjelasan diatas dapat disimpulkan bahwa NEO sebagai cryptocurrency asal Tiongkok membawa potensi untuk menjadikan Tiongkok sebagai negara penyeimbang dan menjadi hegemoni 
baru bagi bidang ekonomi global. Hal tersebut dipengaruhi oleh besarnya angka indeks pertumbuhan Tiongkok yang cepat dan penggunaan NEO yang dapat digunakan secara terdesentralisasi baik melalui cryptomarket cryptomarket besar yang tersebar dihampir semua negara yang terbuka terhadap transaksi ICO maupun melalui developer DApps yang tersebar secara luas termasuk di Amerika Serikat. Bahkan NEO bukan hanya sekedar cryptocurrency saja melainkan sebuah platform yang saling terintegrasi untuk menciptakan cyber economy Tiongkok. Hal ini diperkuat dengan adanya para pengembang pengembang dari Amerika Serikat dan negara negara lain yang ikut mengembangkan DApp berbasis blockchain NEO. Fitur digital identity yang diusung oleh NEO memberikan akses tersendiri bagi NEO dan pemerintah Tiongkok dalam mengetahui segala data transaksi dalam network NEO sehingga transaksi transaksi ilegal dapat dilacak.

\section{Kesimpulan}

Berdasarkan kerangka pemikiran yang telah digunakan oleh peneliti, penelitian ini menemukan jawaban dari rumusan masalah yang ada. Pertama, peneliti telah menemukan beberapa faktor yang mendorong pemerintah Tiongkok melakukan pelarangan transaksi ICO khususnya bitcoin. Faktor pertama yang melatarbelakangi perintah larangan ICO tersebut adalah adanya resiko pecahnya bubble investation. Tiongkok merupakan negara penguasa pasar terbesar Bitcoin selama 20132017, sedangkan nilai tukar Bitcoin hanya ditentukan mekanisme pasar dalam P2P network Bitcoin. Faktor kedua adalah adanya potensi penggunaan Bitcoin sebagai media pendanaan tindakan ilegal. Fitur fitur Bitcoin seperti P2P yang memberikan akses anonym memberikan celah bagi para pelaku tindakan illegal untuk menggunakan Bitcoin sebagai media pendanaan mereka. Faktor terakhir adalah penggunaan listrik yang berlebihan, hal ini disebabkan karena Tiongkok juga merupakan negara dengan industri mining pool Bitcoin terbesar didunia. Murahnya biaya listrik yang disediakan oleh Pemerintah Tiongkok digunakan oleh para pelaku industri Tiongkok beralih menjalankan industri mining pool. Keuntungan yang diperoleh oleh para pelaku industri tidak sebanding dengan biaya listrik yang murah. Selain itu, Bitcoin sebagai cryptocurrency dalam hal ini bukanlah komponen dari pajak yang harus dibayarkan kepada negara. Sehingga negara sama sekali tidak mendapatkan apa apa dengan adanya mining pool tersebut. Selain faktor faktor yang melatar belakangi Pemerintah Tiongkok melakukan larangan terhadap transaksi ICO khususnya Bitcoin, peneliti menemukan bahwa Ekonomi Tiongkok memiliki pengaruh dalam ekonomi global berkaitan dengan penggunaan cryptocurrency. Tiongkok memiliki peran besar dalam perkembangan cryptocurrency, salah satunya bitcoin yaitu sebagai negara yang berhasil menaikkan harga tukar tetinggi Bitcoin dan sebagai negara penambang Bitcoin terbesar. Industri Tiongkok juga hampir selalu memiliki pasar disetiap negaranya. Bahkan pada tahun 2018, Tiongkok menjadi negara pengekspor terbesar ke Amerika Serikat. Besaran nilai ekspor berkaitan erat dengan besaran devisa yang diterima oleh Tiongkok yang berhubungan dengan kebijakan penentuan fluktuasi nilai mata uang untuk menjaga kestabilan harga barang ekspor.

Rencana pengembangan national cryptocurrency merupakan bagian dari the $13^{\text {th }}$ FYP untuk menciptakan cyber economy melalui dukungan terhadap NEO sebagai salah satu platform blockchain asal Tiongkok. Meskipun NEO masih terbilang baru karena baru diluncurkan akhir tahun 2016, tetapi NEO memiliki potensi besar terhadap pasar dunia yang jelas dapat memberikan keuntungan terhadap pemerintah Tiongkok. Hal ini dikarenakan NEO memiliki fitur fitur tambahan yang berbeda dengan Bitcoin yang benar benar mengusung konsep real decentralized. NEO dijalankan dengan konsep semi-decentralized yang memungkinkan pemerintah Tiongkok melalui pengembang 
memiliki akses terhadap network user apabila hal tersebut memang diperlukan. Selain itu, kepopuleran penggunaan NEO terus meningkat seiring dengan peringkat NEO yang tetap dan terus bertahan diatas 20 besar dalam market capital rank. Sedangkan perlu diketahui bahwa besaran ranking yang didapatkan merupakan jumlah capital market yang besarannya ditentukan oleh besarnya penggunaan yang digunakan oleh seluruh user yang ada didunia. Sebagaimana yang telah dijelaskan diatas bahwa penggunaan NEO telah tersebar diberbagai negara didunia dan terus melebar tidak hanya dalam bidang currency. Perkembangan NEO yang terus meningkat memungkinkan Tiongkok memiliki potensi untuk memperkuat ekonomi Tiongkok sebagai bagian dari upaya soft balancing Tiongkok terhadap kekuatan unipolar Amerika. Selain itu, terdapat fitur yang diusung oleh NEO sebagai bentuk dukungan terhadap rencana Pemerintah Tiongkok untuk mewujudkan cyber economy, pengembang NEO mengusung digital identity dan digital certificate sebagai bentuk akses dan jaminan dari pemerintah Tiongkok kepada seluruh user NEO. Selain itu, penggunaan NEO dimasa depan juga memiliki potensi untuk menjadikan Tiongkok sebagai negara yang memiliki hegemon baru baik dikawasan regional maupun internasional, sebagaimana yang telah dijelaskan oleh Dobija bahwa untuk menjadi global currency nantinya diperlukan sebuah trobosan dari teknologi yang dapat membantu terhadap sektor perekonomian. Peningkatan nilai capital market NEO memberikan keuntungan tersendiri bagi pemerintah Tiongkok berkaitan dengan stabilisasi fluktuasi nilai tukar Yuan. Sehingga dimasa mendatang, Tiongkok memiliki potensi untuk membentuk sebuah hegemoni baru yang sebenarnya sudah dapat dilihat pada masa sekarang, dimana beberapa komponennya adalah nilai ekspor, devisa, dan cryptocurrency yang secara tidak langsung memberikan pengaruh terhadap kekuatan perekonomian Tiongkok. Selain itu, dalam hal tersebut NEO dapat disebut sebagai alat dalam upaya soft balancing terhadap hegemoni
Amerika yang sudah terbentuk sejak perang dingin dimulai.

Dalam penelitian ini, peneliti lebih menekankan kepada alasan pemerintah Tiongkok melakukan pelarangan ICO khususnya Bitcoin dan justru melakukan pengembangan cryptocurrency sendiri dimana hal tersebut berlawanan dengan kebijakan sebelumnya dan bukan merupakan perbandingan antar cryptocurrency. Oleh karena itu, meskipun NEO belum memiliki capital market sebesar Bitcoin namun dukungan dari Pemerintah Tiongkok terhadap pengembangan NEO dengan dasar usaha pencapaian the $13^{\text {th }}$ FYP merupakan bagian dari upaya pemerintah Tiongkok untuk melakukan soft balancing dan memiliki potensi untuk menciptakan hegemon baru baik dikancah regional ataupun internasional. Hal tersebut berkaitan dengan menurunnya indeks saham Amerika akibat adanya kebijakan proteksi yang dilakukan oleh Donald Trump untuk menyeimbangkan neraca perdagangan Amerika. Kebijakan tersebut membawa dampak bergesernya minat investor dari IPO menjadi ICO. Selain itu, persebaran NEO didukung dengan adanya fitur smart contract yang memungkinkan developer dari berbagai negara termasuk Amerika ikut mengembangkan NEO melalui DApps sehingga user NEO semakin meningkat.

\section{Daftar Pustaka}

All Cryptocurrencies | Coinmarketcap. (2019, January 10). Retrieved from https://coinmarketcap.com/all/views/all I.

Blum, S. (2003). Chinese Views of US Hegemony. Journal of Contemporary China, 239 - 264.

Bull , H., \& Herbert Butterfield, and Kenneth Walt. (1979). Theory of International Politics. California: Addison. 
CipherTrace Cryptocurrency Intelligence. (2018 ). Cryptocurrency Anti Money Laundring Report . CipherTrace.

Coin Market Cap. (n.d.). All Cryptocurrencies. Retrieved from Coin Market Cap: https://coinmarketcap.com/all/views/al 1/

Costigan, T. (2018). The US dollar and its challenges: American hegemony in the 21 st century. Journal Labor and Society.

Dirzauskaite, G., \& Ilinca, N. C. (2017). Understanding "Hegemony" in International Relations Theories. Development and International Relations Aalborg University, 18.

Dobija, M. (2014). The Global Currency Area a Way to Constructively End the Era of Reserve Currency. Modern Economy .

Dunne, T., \& C. Schmidt, B. (2001). Realism. In J. Baylis, \& S. Smith, The Globalization of World Politics (pp. 161-183). New York: Oxford.

European Parliament . (2018). Virtual Currencies and Terrorist Financing : Assesing the risk and valuating response. Brussels: Policy Department for Citizens' Rights and Constitutional Affairs European Parliament.

FBI . (2013). Manhattan U.S. Attorney Announces Seizure of Additional \$28 Million Worth of Bitcoins Belonging to Ross William Ulbricht, Alleged Owner and Operator of "Silk Road" Website . New York: FBI New York Press Office.

Focus Economics . (2018, Juni ). China Industry May 2018. Retrieved from Focus Economics: https://www.focuseconomics.com/countries/china/news/i ndustry/manufacturing-activities-drag- on-industrial-production-growth-inmay

Friedman, M. P. and Long, T. (2015 ). Soft balancing in the Americas: Latin American opposition to U.S. intervention, $1898 \quad-1936$. International Security, 120-156.

Hadiwinata, B. S. (2017). Realisme dan Neorealisme. In Studi dan Teori Hubungan Internasional (p. 102). Jakarta: Yayasan Pustaka Obor Indonesia.

Hokroh, M. (2013). Examining the Chinese Exchange Rate Reform and the Possibility of the Chinese Yuan Becoming a Regional Trade Currency. Research in Applied Economics.

Oyedele, A. (2017, Januari 18). One country dominates the global bitcoin market. Retrieved from Business Insider Singapore: https://www.businessinsider.sg/bitcoin -trading-china-yuan-remnibi-2017$1 /$ ? $\mathrm{r}=\mathrm{US} \& \mathrm{IR}=\mathrm{T}$

Pape, R. A. (2005). Soft Balancing against the United States. International Security, $30,7-45$.

Pinguin Intellegence. (2017). 2017 We Chat User and Business Ecosystem Report .

Savona, E. (2014). Organised crime numbers. Global Crime , 1-9.

Seetharaman, A., \& A.S Saravanan, Nitin Patwa, Jigar Mehta. (2017). Impact of Bitcoin as a World Currency. Accounting and Finance Research, 117.

Stalinsky, S. (2018, Agustus 03). Terrorists have been using bitcoin for four years, so what's the surprise? Retrieved from The Hill: https://thehill.com/opinion/cybersecuri ty/377415-terrorists-have-been-using- 
129 Pungki Retnowati dan Ika Riswanti Putranti | Bitcoin vis a vis NEO: Upaya Tiongkok menuju Penyeimbang Kekuatan Ekonomi Amerika Serikat dalam Kacamata Hegemoni dan Soft Balancing

bitcoin-for-four-years-so-whats-the-

surprise

Statista. (2017). Annual number of ransomware attacks worldwide from 2014 to 2017 (in millions). Retrieved from Statista: https://www.statista.com/statistics/494 947/ransomware-attacks-per-yearworldwide/

Statista. (2018). Global electricity prices in 2018, by select country (in U.S. dollars per kilowatt hour). Retrieved from Statista:

https://www.statista.com/statistics/263

492/electricity-prices-in-selectedcountries/

Yeşiltaş, M. (2009). SOFT BALANCING IN TURKISH FOREIGN POLICY: THE CASE OF THE 2003 IRAQ WAR. Perceptions, 1-27. 